\title{
Solar Energy, Conservation, and Rental Housing
}

Alice Levine

Jonathan Raab
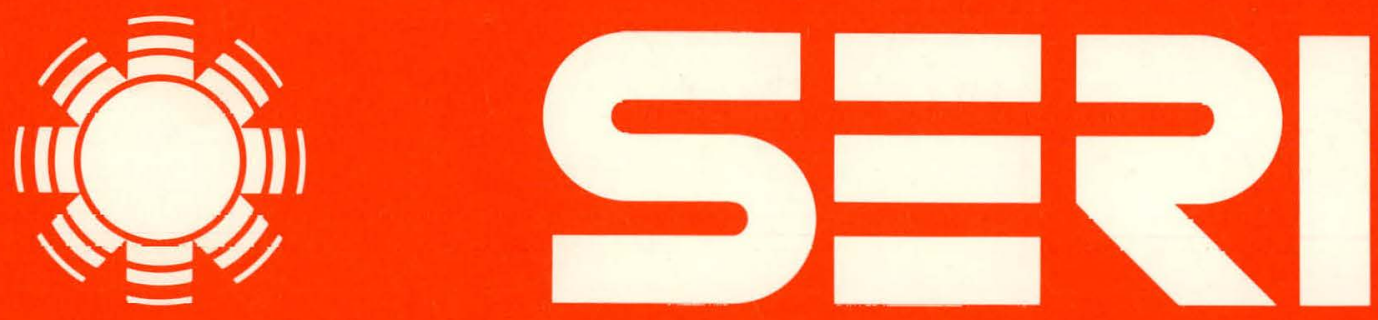

\section{Solar Energy Research Institute}

A Division of Midwest Hesearch Institute

1617 Cole Boulevard

Golden, Colorado 80401

Operated for the

U.S. Department of Energy

under Contract No. EG-77-C-01-4042 


\section{DISCLAIMER}

This report was prepared as an account of work sponsored by an agency of the United States Government. Neither the United States Government nor any agency Thereof, nor any of their employees, makes any warranty, express or implied, or assumes any legal liability or responsibility for the accuracy, completeness, or usefulness of any information, apparatus, product, or process disclosed, or represents that its use would not infringe privately owned rights. Reference herein to any specific commercial product, process, or service by trade name, trademark, manufacturer, or otherwise does not necessarily constitute or imply its endorsement, recommendation, or favoring by the United States Government or any agency thereof. The views and opinions of authors expressed herein do not necessarily state or reflect those of the United States Government or any agency thereof. 


\section{DISCLAIMER}

Portions of this document may be illegible in electronic image products. Images are produced from the best available original document. 


\author{
Printed in the United States of America \\ Available from: \\ National Technical Information Service \\ U.S. Department of Commerce \\ 5285 Port Royal Road \\ Springfield, VA 22161 \\ Price: \\ Microfiche $\$ 3.00$ \\ Printed Copy $\$ 5.25$
}

\begin{abstract}
NOTICE
This report was prepared as an account of work sponsored by the United States Government. Neither the United States nor the United States Department of Energy, nor any of their employees, nor any of their contractors, subcontractors, or their employees, makes any warranty, express or implied, or assumes any legal liability or responsibility for the accuracy, completeness or usefulness of any information, apparatus, product or process disclosed, or represents that its use would not infringe privately owned rights.
\end{abstract}


SER I /RR-744-901

UC CATEGORY: UC -58

SOLAR ENERGY, CONSERVATION, AND RENTAL HOUSING

\author{
ALICE LEVINE \\ JONATHAN RAAB
}

MARCH 1981

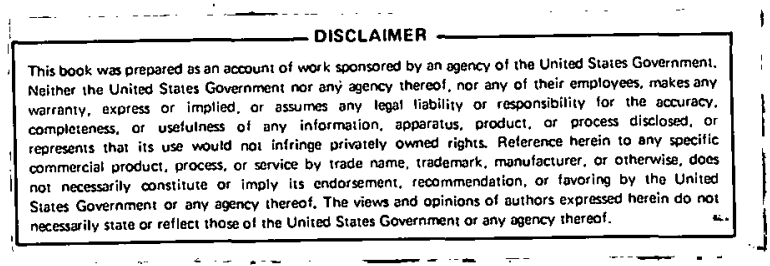

PREPARED UNDER TASK NO. 5637.10

\title{
Solar Energy Research Institute
}

A Dlvision ol Midwest Research Institute

1617 Cole Boulevard

Golden, Colorado 80401

Prepared for the

U.S. Department of Energy

Contract No. EG-77-C-01-4042 
THIS PAGE

\section{WAS INTENTIONALLY LEFT BLANK}




\section{PREFACE}

Rental housing constitutes one-third of U.S. housing stock, yet currently little incentive exists to improve its energy efficiency. This report documents some problems and proposes some solutions, such as creating incentives to invest in conservation and solar energy devices for rental housing. To provide a background, the report first describes the rental housing market. Five major energy/conservation program elements are identified, and examples of state and local solutions are given, with advantages and disadvantages of each. The report emphasizes that solutions will vary with local housing market conditions.

This work was completed in the Community and Consumer Branch in conjunction with three tasks at the Solar Energy Research Institute (SERI): (1) Social Impact Assessment of Solar Energy, (2) Community Energy Planning, and (3) Community Energy Implementation.

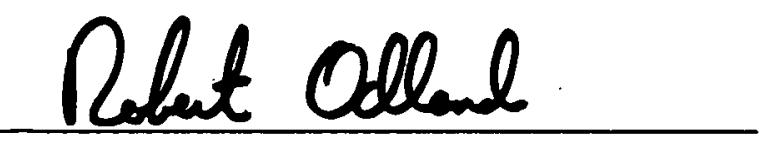

Robert Odland, Chief

Community and Consumer Branch

$\Lambda$ pproved for

SOLAR ENERGY RESEARCH INSTITUTE

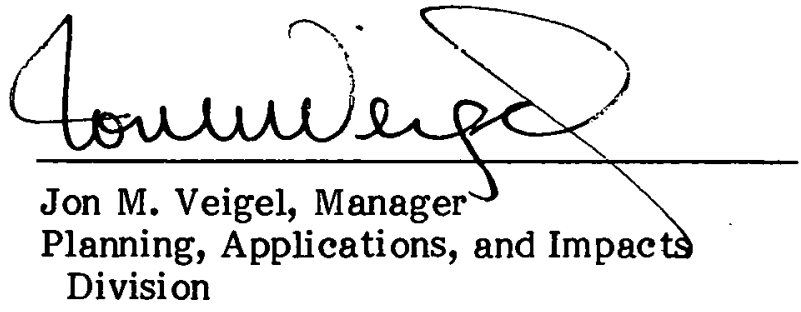




\section{THIS PAGE}

\section{WAS INTENTIONALLY \\ LEFT BLANK}




\section{SUMMARY}

\section{OBJECTIVE}

Rental housing represents about $35 \%$ of total U.S. housing stock. However, policies encouraging energy conservation and the use of solar energy in the residential sector have virtually ignored the complexities of achieving energy efficiency in rental housing. This report characterizes the rental housing market, defines energy-related problems, and offers some tools for building solutions to those problems.

The report is directed to two audiences. First, it provides information to federal, state, and local groups and policy makers concerned with problems of energy in the rental sector. Second, the report provides the U.S. Department of Energy (DOE) with information about the rental housing market, including barriers to conservation efforts and solar energy investments in that sector and descriptions and analyses of state and local policies for removing those barriers and providing incentives for investment.

Although technological problems associated with conservation and solar energy use in rental housing are also barriers to investment, we feel that economic, political, social, and institutional obstacles are more significant now. These, therefore, are addressed in this report.

\section{DISCUSSION}

The report first characterizes the national rental housing market in terms of building structure, region, urban/rural profile, age of rental housing stock, renters' incomes, master versus separate metering of utilities, rent control, and rental housing owners' investment criteria. As part of this market breakdown, we describe the economic, political, social, and institutional barriers to investment in conservation techniques, or solar energy technology, or both. Finally, we offer examples of state and local programs designed to address the rental housing/energy issue. Since these are all new programs, our analysis of them is preliminary, of ten based more on our knowledge of the rental housing market than on actual program operating results.

The program examples are divided into five types: (1) programs for renlers; (2) economic incentives for rental property owners; (3) leasing of solar energy systems; (4) mediation; and (5) regulation. While no one example restricts itself to only one program type, distinguishing among program types may prove useful to policy makers as they design new programs that will besl uddiess local rental market issues.

Data on existing programs were collected by means of telephone interviews. Supporting data that describe the rental housing market were obtained from the literature. Future research will enable us to collect primary data from renters and rental housing owners to substantiate our findings further and provide more detailed recommendations for policies or program action.

\section{CONCLUSIONS AND RECOMMENDATIONS}

The preliminary nature of this report and the great diversity in local rental housing markets make it impossible to recommend a single policy or program as a solution to energy- 
related rental housing problems. However, three important general findings are noted. First, in designing an energy policy it is essential to differentiate between residential rental property and owner-occupied property. Investment criteria are of ten different for these two property types. It is also important to disaggregate the rental housing sector itself. Local rental markets vary, and so do the solutions to their energy problems.

Second, for anything more than no-cost or low-cost conservation items, it is more practical to direct incentive programs to rental housing owners rather than to tenants. Programs for tenants are important, but they do little if anything to make permanent, energy efficiency-enhancing changes to the property itself.

Third, it is important that energy policies designed to affect rental housing combine two or more of the five program types outlined in the report (see also p. v of this Summary). No single program type is likely to provide sufficient incentives or results. Again, the optimal combination depends upon local rental housing market conditions. 
TABLE OF CONTENTS

1.0 Introduction $\ldots \ldots \ldots \ldots \ldots \ldots \ldots \ldots \ldots \ldots \ldots \ldots \ldots \ldots \ldots \ldots \ldots \ldots \ldots \ldots$

1.1 Purpose of the Report ............................. 1

1.2 Rental Housing and Energy-A Statement of the Problem ........... 1

2.0 Characteristics of the Rental Housing Market .................. 3

2.1 Building Structure $\ldots \ldots \ldots \ldots \ldots \ldots \ldots \ldots \ldots \ldots \ldots \ldots \ldots \ldots \ldots \ldots \ldots$

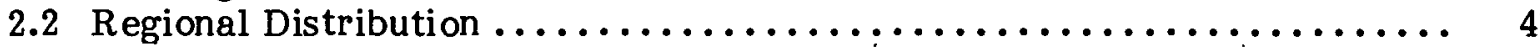

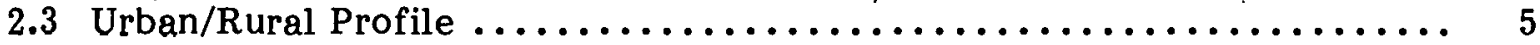

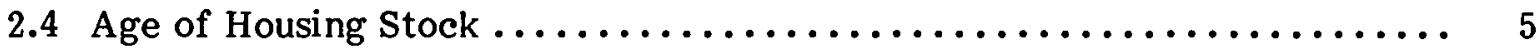

2.5. Renters' Incomes ............................... 6

2.6 Federal Assistance for Rental Housing .................. 7

2.7 Summary of Rental Housing Characteristics ................. 8

3.0 Energy Use in the Rental Sector.$\ldots \ldots \ldots \ldots \ldots \ldots \ldots \ldots \ldots \ldots \ldots \ldots \ldots$

3.1 Energy Use Patterns ............................... 9

3.2 Who Pays the Energy Bills? ........................... 11

3.3 The Effects of Who Pays Energy Costs on Conservation and

Solar Energy Investments ............................ 15

3.3.1 Separate Metering vs. Master Metering................. 15

3.3 .2 Rent Control ................................. 16

3.4 The Potential for Tenants to Invest $\ldots \ldots \ldots \ldots \ldots \ldots \ldots \ldots \ldots \ldots \ldots \ldots$

3.5 Summary: Energy Use in the Rental Sector ................. 17

4.0 Investment Criteria of Rental Housing Owners $\ldots \ldots \ldots \ldots \ldots \ldots \ldots \ldots \ldots \ldots$

4.1 Declining Profitability in the Rental Housing Market-

Owners' Responses ................................ 19

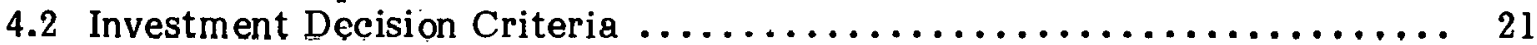

4.2.1 Types of Profit and Forms of Ownership ............... 21

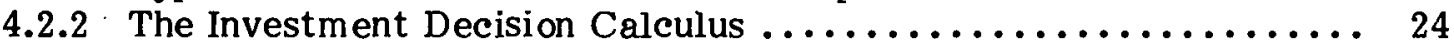

4.2 .3 Pref erred Incentives $\ldots \ldots \ldots \ldots \ldots \ldots \ldots \ldots \ldots \ldots \ldots \ldots \ldots \ldots \ldots \ldots \ldots \ldots$

4.3 Summary: Owners' Investment Decisions Criteria .............. 28

5.0 Federal, State, and Local Investment Incentive Programs . . . . . . . . . 29

5.1 Federal Programs .................................... 29

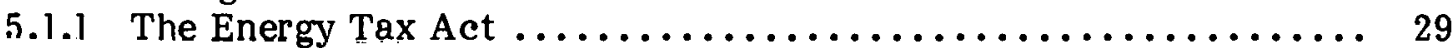

5.1.2 The Solar Energy and Energy Conservation

Development Bank ............................ 29

5.1.3 The Residential Conservation Service.................. 31

5.1.4 Federal Programs for Rental Housing .................. 31

5.1.5 Summary of Federal Rental Housing/Energy Programs........... 33

5.2 State and Local Programs .............................. 34 
TABLE OF CONTENTS (Concluded)

$\underline{\text { Page }}$

5.3 Types of Incentives $\ldots \ldots \ldots \ldots \ldots \ldots \ldots \ldots \ldots \ldots \ldots \ldots \ldots \ldots \ldots \ldots \ldots \ldots \ldots$

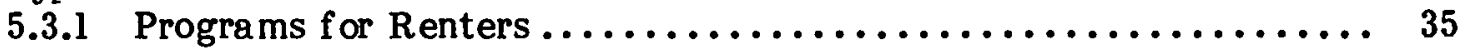

5.3.2 Economic Incentives for Rental Property Owners . . . . . . . . . . 37

5.3 .3 Leasing of Solar Energy Systems ..................... 40

5.3 .4 Mediation .................................. 42

5.3.5 Regulatory Actions Geared to Rental Housing Owners .......... 44

5.3.6 Summary of Incentive Programs .................... 47

6.0 Conclusions $\ldots \ldots \ldots \ldots \ldots \ldots \ldots \ldots \ldots \ldots \ldots \ldots \ldots \ldots \ldots \ldots \ldots \ldots \ldots \ldots$

6.1 Major Findings $\ldots \ldots \ldots \ldots \ldots \ldots \ldots \ldots \ldots \ldots \ldots \ldots \ldots \ldots \ldots \ldots \ldots \ldots$

6.2 Recommendations $\ldots \ldots \ldots \ldots \ldots \ldots \ldots \ldots \ldots \ldots \ldots \ldots \ldots \ldots \ldots \ldots \ldots \ldots \ldots$

7.0 Bibliography $\ldots \ldots \ldots \ldots \ldots \ldots \ldots \ldots \ldots \ldots \ldots \ldots \ldots \ldots \ldots \ldots \ldots \ldots \ldots \ldots \ldots$

Appendix A. Interviews $\ldots \ldots \ldots \ldots \ldots \ldots \ldots \ldots \ldots \ldots \ldots \ldots \ldots \ldots \ldots \ldots \ldots \ldots \ldots \ldots$

Appendix B. Ordinancç Cited .......................... 5 y 


\section{LIST OF TABLES}

Page

2-1 Rental Housing Building Structure Composition, $1977 \ldots \ldots \ldots \ldots \ldots \ldots$

2-2 Number of Renter-Occupied Units, by Region ................... 4

2-3 Regional Distribution of Rental Housing Types .................. 4

2-4 Urban/Rural Distribution of Rental Housing................... 5

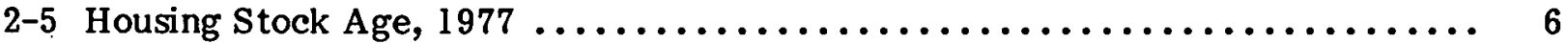

2-6 Income Comparison: Homeowners vs. Renters, $1977 \ldots \ldots \ldots \ldots \ldots \ldots \ldots \ldots$

2-7 Federally Subsidized Rental Housing, $1977 \ldots \ldots \ldots \ldots \ldots \ldots \ldots \ldots \ldots \ldots \ldots$

2-8 Multifamily Housing Starts $\ldots \ldots \ldots \ldots \ldots \ldots \ldots \ldots \ldots \ldots \ldots \ldots \ldots \ldots \ldots$

3-1 Energy Consumption in Multifamily Units (5 or More), $1974 \ldots \ldots \ldots \ldots \ldots \ldots$

3-2 Residential Space Heating Fuel $\ldots \ldots \ldots \ldots \ldots \ldots \ldots \ldots \ldots \ldots \ldots \ldots \ldots$

3-3 Residential Space and Water Heating Fuel Sources, by Region ........... 11

3-4 How Rental Utility Bills Are Paid ......................... 12

3-5 How Rental Utility Bills Are Paid, by Structure Type ............... 13

3-6 How Rental Utility Bills Are Paid, by Region ..................... 14

3-7 Master Metering in New Construction (State Public Utility Commissions) $\ldots \ldots \ldots \ldots \ldots \ldots \ldots \ldots \ldots \ldots \ldots \ldots \ldots \ldots \ldots \ldots$

5-1 Maximum Subsidies Allowed for̀ Conservation Expenditures by the Solar Energy and Energy Conservation Development Bank . . . . . . . . 30

5-2 Maximum Subsidies Allowed for Solar Energy Expenditures by the Solar Energy and Energy Conservation Development Bank

\section{LIST OF FIGURES}

4-1 Change in Operating Revenues and Expenses for 189 Apartment Buildings Properties: $1970-1976 \ldots \ldots \ldots \ldots \ldots \ldots \ldots \ldots \ldots \ldots \ldots \ldots \ldots \ldots . \ldots . \ldots \ldots$

4-2 A Breakdown of Apartment Ownership Forms-1976 .............. 23 


\section{THIS PAGE}

\section{WAS INTENTIONALLY \\ LEFT BLANK}




\section{SECTION 1.0}

\section{INTRODUCTION}

\subsection{PURPOSE OF THE REPORT}

This report is intended for two audiences. The first, the U.S. Department of Energy (DOE), will receive information on the residential rental market, including barriers to conservation and solar energy investments that exist in that sector, and descriptions and analyses of state and local policies for removing those barriers and providing incentives. The second audience comprises federal, state, and local groups and policy makers concerned with problems of energy in the rental sector.

In this report, we investigate the economic, political, social, and institutional barriers to investments in energy efficient technology for rental housing. Although technological problems associated with conservation and solar energy use in rental housing are also a barrier to greater levels of investment, we feel that the former barriers are currently more significant; therefore, technological problems are not addressed here.

\subsection{RENTAL HOUSING AND ENERGY - A STATEMENT OF THE PROBLEM}

The residential sector is quite diverse. Decisions about whether to invest in home improvements related to energy vary a great deal. A primary difference in the investment decision process exists between homeowners and rental housing owners. To date, most programs, largely federal, that are designed to promote residential energy conservation and the use of solar energy in the residential sector are more likely to affect homeowners' decisions than the investment decisions of rental housing owners. This bias virtually ignores $35 \%$ of all housing units in the United States-rental housing. It is important, therefore, to disaggregate the residential sector into owner-occupied and rental housing in order to impact this substantial portion of housing in the United States.

But at federal, state, and local levels, people in government and community organizations are recognizing that encouraging energy conservation and solar energy use in rental housing are difficult tasks. Many rental property owners are not directly responsible for the utility bills. In the majority of cases, rental housing is separately metered; and tenants, who would be the major beneficiaries of decreased energy costs resulting from conservation and solar investments in rental property, are both legally and financially constrained from making those investments because they do not own the buildings. In master-metered buildings where owners pay utility bills directly, they are usually able to pass on energy costs to tenants through rent increases. In either case, there is presently littlc economic incentive to invest in conservation or solar energy improvements.

Findings of this report indicate that, for anything more than low-cost or no-cost conservation efforts, it is more practical to direct incentive programs to rental property owners than to tenants. At the same time, it is important that such programs are properly tailored to reflect the diversity within the rental sector. To create effective programs, we must look carefully at the rental housing owner's investment decision-making process. We also must have a clear understanding of the context in which those decisions are made; that is, existing institutions that affect the relationship between the landlord and tenant, such as government housing programs, rent control, and whether the building is master-metered or separately metered for utilities. 
This report describes both investment decisions and their general contexts. With this information, policy makers may be able to direct policies and programs to influence decisions and encourage investments in conservation and solar energy in the rental housing sector. The first part of the report reviews problems of effective policy design, describes the rental market and its actors, and explains how investment decisions are made. In the second part, we describe and analyze a variety of approaches to program design that are being advocated and implemented to encourage conservation and the use of solar energy in rental housing. Federal programs are described briefly. However, our focus is on state and local programs because these seem better able to deal with the local diversity of the rental housing market: diversities in climate, conventional fuel use patterns and type, building stock, and state and local ordinances and regulations. 


\section{SECTION 2.0}

\section{CHARACTERISTICS OF THE RENTAL HOUSING MARKET}

The residential rental sector constitutes a significant portion of U.S. housing. In 1977, there were 26-1/2 million rental units in the United States; that figure represents $35 \%$ of the entire housing stock (U.S. Department of Commerce, Bureau of the Census, Annual Housing Survey, 1977).

According to a report by the General Accounting Office (GAO 1979), renters are now faced with the nation's lowest recorded vacancy rate-5\%. The market is typified also by fewer housing starts, increasing condominium conversion, and abandonment. Rising utility costs are part of the cause, exacerbating trends of rapidly rising operating costs throughout the rental sector. The GAO characterizes the situation as an emergency.

The rental sector, like the residential sector in general, is varied. The differences in building structure, geographic distribution, forms of ownership, and renter demographics pose diverse technical, institutional, and economic barriers to the successful implementation of conservation techniques and solar energy use in rental housing. Differences between the owner-occupied and rental portions of the residential sector and differences within the rental housing sector itself are critical because they demand carefully tailored policies that will enhance the energy efficiency of all housing. Therefore, in this section, we explore both differences between rental housing and owner-occupied housing as well as the diversity within the rental housing sector itself.

\subsection{BUILDING STRUCTURE}

Associating rental housing primarily with multifamily structures is a common misrepresentation of this sector. Multifamily structures with five or more units actually constitute only $38.5 \%$ of U.S. rental housing units.

Table 2-1. RENTAL HOUSING BUILDING STR UCTURE COMPOSTTION, 1977

\begin{tabular}{lcc}
\hline $\begin{array}{c}\text { Units } \\
\text { per Structure }\end{array}$ & $\begin{array}{c}\text { Number } \\
\text { (thousands) }\end{array}$ & $\begin{array}{c}\text { \% of } \\
\text { Total }\end{array}$ \\
\hline 1 & 8,243 & $31.0 \%$ \\
$2-4$ & 7,326 & 27.0 \\
$5-19$ & 5,838 & 22.0 \\
$20-49$ & 1,992 & 7.5 \\
$50+$ & 2,460 & 9.0 \\
Mobile/trailer & 656 & 2.5 \\
$\quad$ Total & $\overline{26,515}$ & $\overline{100.0}$ \\
\hline
\end{tabular}

Source: U.S. Department of Commerce, Bureau of the Census, Annual Housing Survey 1977. 
The wide range of structure types in the rental sector presents different obstacles to conservation and solar utilization. For instance, installing passive heating and solar water heaters on existing apartment complexes with 50 or more units probably will be technically more complicated than retrofitting a single-family rental unit because of space and orientation problems. Also, different structure types may be associated with different forms of ownership; not all owners and investors will react similarly to financial incentives to conserve energy or use alternative energy sources.

\subsection{REGIONAL DISTRIBUTION}

Rental housing stock is spread fairly evenly throughout the United States. While Southern states now have the greatest percentage of rental structures and the West has the smallest, both the West and South have been gaining rental housing (as well as owneroccupied housing) more rapidly than the Northeast or North Central regions have.

Table 2-2. NUMBER OF RENTER-OCCUPIED UNITS, BY REGION

\begin{tabular}{lccccc}
\hline & $\begin{array}{c}1970 \\
\text { (thousands) }\end{array}$ & $\%$ & $\begin{array}{c}1977 \\
\text { (thousands) }\end{array}$ & $\%$ & \% Change \\
\hline Northeast & 6,556 & $27.9 \%$ & 6,778 & $25.5 \%$ & $-2.4 \%$ \\
North Central & 5,613 & 23.8 & 6,092 & 23.0 & -0.8 \\
South & 6,801 & 28.9 & 8,081 & 30.5 & +1.6 \\
West & 4,579 & 19.4 & $\frac{6,564}{26,515}$ & $\frac{21.0}{100.0}$ & +1.6 \\
$\quad$ Total & 23,559 & 100.0 & $\frac{26,0}{2}$ & \\
\hline
\end{tabular}

Source: GAO 1979, p. 2.

The absolute numbers of rental units are distributed relatively equally among the four regions, but the number of units per building differs significantly from region to region. Table 2-3 shows clearly that the Northeast has far more single-family attached units (30\%), 2 to 4 units (34\%), and large multifamily structures (33\%) than any other region. At the same time, the Northeast has the fewest single-family rental units (9\%) while the South has the most (44\%). The relative regional concentration and composition of the rental housing stock affect both the problems of and future policy solutions for successfully promoting solar and energy conservation in these regions.

Table 2-3. REGIONAL DISTRIBUTION OF RENTAL HOUSING TYPES (\%)

\begin{tabular}{lccccc}
\hline & $\begin{array}{c}\text { Single Detached } \\
\text { Units }\end{array}$ & $\begin{array}{c}\text { Single Attached } \\
\text { Units }\end{array}$ & $\begin{array}{c}2-4 \\
\text { Units }\end{array}$ & $\begin{array}{c}5+ \\
\text { Units }\end{array}$ & Mobile Units \\
\hline Northeast & $9 \%$ & $30 \%$ & $34 \%$ & $33 \%$ & $7 \%$ \\
North Central & 21 & 22 & 26 & 21 & 19 \\
South & 44 & 27 & 22 & 25 & 54 \\
West & 26 & 21 & 18 & 21 & 19 \\
\hline
\end{tabular}

Source: U.S. Department of Commerce, Bureau of the Census, Annual Housing Survey 1977. 


\subsection{URBAN/RURAL PROFILE}

The concentration of rental housing in urban areas in the United States has implications for incorporating energy policies for rental housing in overall government urban policy. Approximately $82 \%$ of rental housing is located in urban areas compared with only $66 \%$ of owner-occupied units. In many cities, rental housing units outnumber owner-occupied units. The concentration of rental housing in urban areas implies higher densities for a majority of rental housing. While higher density provides many opportunities for energy conservation, it may be more difficult to provide or guarantee solar access for highdensity urban rental units than for low-density housing.

Table 2-4. URBAN/RURAL DISTRIBUTION OF RENTAL HOUSING (thousands)

\begin{tabular}{|c|c|c|c|}
\hline & & Owner & Rental \\
\hline \multirow{3}{*}{\multicolumn{2}{|c|}{$\begin{array}{l}\text { Urban total } \\
\text { Within SMSA } \\
\text { Outside SMSA }\end{array}$}} & 31,890 & 21,809 \\
\hline & & 25,727 & 18,532 \\
\hline & & 6,163 & 3,277 \\
\hline \multirow{3}{*}{\multicolumn{2}{|c|}{$\begin{array}{l}\text { Rural total } \\
\text { Nonfarm } \\
\text { Farm }\end{array}$}} & 16,875 & 4,705 \\
\hline & & 14,712 & 4,251 \\
\hline & & 2,164 & 455 \\
\hline \multirow{2}{*}{\multicolumn{2}{|c|}{$\begin{array}{l}\text { Within SMSA } \\
\text { Outside SMSA }\end{array}$}} & 5,559 & 1,496 \\
\hline & & 11,316 & 3,210 \\
\hline \multicolumn{2}{|c|}{ Total } & 48,765 & 26,515 \\
\hline \multicolumn{4}{|c|}{$\begin{array}{l}\text { Source: U.S. Departinent of Commerce, } \\
\text { Bureau of the Census, Annual }\end{array}$} \\
\hline \multicolumn{4}{|c|}{$\begin{array}{l}{ }^{a} \text { SMSA-standard metropolitan statistical } \\
\text { area. }\end{array}$} \\
\hline
\end{tabular}

\subsection{AGE OF HOUSING STOCK}

One important difference between rental housing and owner-occupied housing is that the rental stock in the United States is older. As shown in Table 2-5, 41.4\% of rental housing in use today was built before 1939. This figure compares with only $27.6 \%$ of the owneroccupied units built during the same period. 
Table 2-5. HOUSING STOCK AGE, 1977

\begin{tabular}{lcccc}
\hline Year Built & $\begin{array}{c}\text { Owner-Occupied } \\
\text { (thousands) }\end{array}$ & $\%$ & $\begin{array}{c}\text { Rental } \\
\text { (thousands) }\end{array}$ & $\%$ \\
\hline Before 1939 & 13,484 & $27.6 \%$ & 10,988 & $41.4 \%$ \\
$1940-1949$ & 4,874 & 10.0 & 2,576 & 9.7 \\
$1950-1959$ & 9,964 & 20.4 & 3,196 & 12.1 \\
$1960-1964$ & 5,368 & 11.0 & 2,367 & 8.9 \\
$1965-1970$ & 5,752 & 11.8 & 3,099 & 11.7 \\
$1970-1977$ & 9,320 & 19.1 & 4,289 & 16.2 \\
Total & 48,764 & 100.0 & 26,515 & 100.0 \\
\hline
\end{tabular}

Source: U.S. Department of Commerce, Bureau of the Census, Annual Housing Survey, 1977.

The age of housing in the United States, for the most part, is directly correlated with the structures' energy efficiency. Of existing structures built before 1939, approximately $33 \%$ have no ceiling insulation and $41 \%$ have no wall insulation (DOE 1980). Similar deficiencies are found in only $5 \%$ and $6 \%$, respectively, of units built af ter 1975 . These numbers indicate that energy conservation and solar energy measures are needed urgently to improve the energy efficiency of a large proportion of rental housing units. For example, the condition of heating equipment in the rental sector is generally poorer than in the owner-occupied sector. While only $7.5 \%$ of owner-occupied units have no heating equipment or are lacking adequate heating equipment, that percentage compares with $11.2 \%$ in the rental sector (DOE 1979). Futhermore, in the winter of $1976,5.8 \%$ of the owneroccupied units had heating equipment failures compared with $9.7 \%$ in the rental sector. During 1976, 268,000 rental units experienced four or more breakdowns in heating equipment, compared with only 123,000 units in the entire owner-occupied sector. Most rental housing is less energy efficient and has more poorly maintained heating and cooling equipment than owner-occupied housing.

\subsection{RENTERS' INCOMES}

Renters generally have lower incomes than homeowners. In 1977, the median income for renters was $\$ 8,800$, while for homeowners it was $\$ 16,000$. Renters, therefore, are less able to afford rising energy costs, whether paid directly or paid indirectly through rents. Less income also makes renters less likely than homeowners to invest in conservation or solar energy. In addition, renters face legal and financial difficulties in investing in conservation or solar energy devices for property not their own.

Table 2-6. INCOME COMPARISON: HOMEOWNERS VS. RENTERS, 1977

\begin{tabular}{lcccc}
\hline Income (\$) & $\begin{array}{c}\text { No. of Homeowners } \\
\text { (thousands) }\end{array}$ & $\%$ & $\begin{array}{c}\text { No. of Renters } \\
\text { (thousands) }\end{array}$ & $\%$ \\
\hline$<7,000$ & 9,469 & $19.4 \%$ & 10,723 & $40.4 \%$ \\
$7,000-10,000$ & 4,797 & 9.8 & 4,232 & 16.0 \\
$10,000-15,000$ & 8,571 & 17.6 & 5,328 & 20.1 \\
$\geq 15,000$ & 25,929 & 53.2 & 6,232 & $\frac{23.5}{100.0}$ \\
Total & 48,766 & 100.0 & $\frac{6,515}{26,5}$ & 100.0 \\
\hline
\end{tabular}

Source: GAO 1979, p.8. 
Table 2-6 shows that the rental housing sector comprises a far greater percentage of low-income households than does the owner-occupied sector. While only about $30 \%$ of homeowners made less than $\$ 10,000$ in 1977 , about $56 \%$ of renters made less than $\$ 10,000$; and $55 \%$ of all low-income households are renters (Corsin, p. 17). Low-income renters pay a greater percentage of their incomes for rent than middle- or high-income renters do. Of those renters paying more than $35 \%$ of their income for rent, $86 \%$ had incomes under $\$ 7,000$ (GAO 1979).

Besides suffering relatively high rental payments, low-income renters are also in the greatest need of assistance to pay their bills. Although low-income households consume less energy than the national average, they spend $30 \%$ to $40 \%$ of their incomes for energy. Middle-income households in identical climates must pay only $7 \%$ to $10 \%$ of their incomes for energy (NCAT 1979, p. 12).

In general, low-income renters occupy the least energy-efficient structures. Of $11 \mathrm{mil}-$ lion rental units built before $1939,64 \%$ are occupied by families earning under $\$ 10,000$ (DOE 1977).

While most middle-income and luxury housing has central heating, one-third of lowincome units have no central heating, and $39 \%$ of those units lack any kind of temperature control for their heating system. While this statistic covers the entire residential sector, over half of low-income households rent (NCAT 1979, p. 12).

\subsection{FEDERAL ASSISTANCE FOR RENTAL HOUSING}

In April 1979, the U.S. Department of Housing and Urban Development (HUD) estimated that 10.1 million low-income renter households needed housing assistance (GAO 1979, p. 26). At that time, only 2 million households were receiving assistance through various federal housing programs, and an additional half-million units of assisted housing were to be made available by September 1980 (GAO 1979, p. 21). By March 1979, HUD had reserved funds to subsidize rent payments in 1.2 million low-income units through Section 8 funding (GAO 1979, p. 22). Meanwhile, as of 1977, public housing and federal rent-subsidized housing already represented $10 \%$ of all rental housing.

I'abİe 2̈-7. FEDERALLY SUBSIDIZED RENTAL HOUSING, 1977

\begin{tabular}{lcr}
\hline \multicolumn{1}{c}{$\begin{array}{c}\text { Rental } \\
\text { Types }\end{array}$} & $\begin{array}{c}\text { Number } \\
\text { (thousands) }\end{array}$ & $\%$ \\
\hline $\begin{array}{l}\text { Units in public housing projects } \\
\text { Private units with gov't rent }\end{array}$ & 1,897 & $7.3 \%$ \\
subsidies & 670 & 2.6 \\
Private units & 22,925 & 88.7 \\
Not reported & $\frac{336}{25,828}$ & $\frac{1.3}{99.9}$ \\
$\quad$ Total & & \\
\hline
\end{tabular}

Source: U.S. Department of Commerce, Bureau of the Census, Annual Housing Survey 1977. 
The Federal Government is being increasingly pressured to fill the demand for rental housing, as the private sector's investment in new housing starts has decreased to its lowest level in 20 years (GAO 1979, p. 11). Rising operating costs, largely the result of escalating fuel prices, have reduced the profitability of all rental housing, especially lowincome rentals. Investment in new multifamily housing has fallen dramatically. While the number of annual multif amily housing starts has decreased from 906,000 in 1972 to 371,000 in 1977, federal subsidies for housing starts have doubled, from $22 \%$ to $44 \%$. HUD has estimated that by 1980 as much as $60 \%$ of multifamily construction will be federally subsidized and more than $75 \%$ will be subsidized, or federally insured, or both (GAO 1979, p. 25). The decrease in rental housing starts will further aggravate the currently tight rental housing market, and increasing federal involvem ent in rental housing can become a severe burden on federal resources. At the same time, this situation provides an opportunity to direct federal programs in conservation and solar energy use to the rental sector.

Table 2-8. MULTIFAMILY HOUSING STARTS

\begin{tabular}{cccc}
\hline Year & $\begin{array}{c}\text { Multifamily } \\
\text { Housing Starts } \\
\text { (thousands) }\end{array}$ & $\begin{array}{c}\text { Federally Subsi dized } \\
\text { Housing Starts } \\
\text { (thousands) }\end{array}$ & $\%$ \\
\hline 1972 & 906.2 & 199.3 & $22 \%$ \\
1973 & 656.0 & 156.1 & 24 \\
1974 & 277.6 & 78.3 & 28 \\
1975 & 178.3 & 53.4 & 30 \\
1976 & 251.2 & 82.8 & 36 \\
1977 & 357.4 & 127.2 & 44 \\
1978 (est) & 371.2 & 164.6 & $\ddots$ \\
\hline
\end{tabular}

Source: GAO 1979, p. 24.

\subsection{SUMMARY OF RENTAL HOUSING CHARACTERISTICS}

Rental housing, representing more than one-third of all housing in the United States, differs from owner-occupied housing in several important ways. First, rental housing generally is more heavily concentrated in urban areas and in multifamily structures than owner-occupied housing. Furthermore, rental housing stock is, on average, quite a bit older than owner-occupied units, is relatively energy-inefficient, and contains heating and cooling equipment inferior to that of owner-occupied housing. Lastly, 56\% of all renters are low-income (compared with only $28 \%$ of homeowners), and many pay as much as $75 \%$ of their total incomes for rent and energy.

These differences between rental and owner-occupi ed housing suggest the need for carefully tailored policies and programs that take into account these two different housing types as well as the great diversity within the rental sector itself. The distribution of rental housing by structure, regional distribution, urban/rural breakdown, and demographic characteristics (i.e., income, age) of the renters all have critical implications for successful policy formulation. In general, if policy makers hope to encourage greater energy conservation and solar energy use in the residential sector, they will have to design a variety of flexible programs that account for both the differences between rental and owner-occupied housing and the diversity found in the rental sector itself. 


\section{SECTION 3.0}

\section{ENERGY USE IN THE RENTAL SECTOR}

To better understand the problems of energy conservation and the use of solar energy in the rental housing sector, it is necessary to look at the way energy is used in rental housing and to examine the relationship between rental housing owners and tenants regarding energy use. The last part of this section focuses on the way energy costs are paid in the rental sector, and how those arrangements affect potential conservation and solar investments.

\subsection{ENERGY USE PATTERNS}

It is projected that the residential rental sector will use 5.5 quadrillion Btu during 1980. This quantity represents approximately $34 \%$ of all residential energy used. While singlefamily units account for only $31 \%$ of all rental housing, $42 \%$ of the energy consumed by the rental housing sector will occur in single-family rentals (Ashworth et al. 1980, p. 13). Energy use levels in single-family rentals are higher than in multifamily rentals generally because of larger dwelling and household sizes, separate heating systems, and lack of common walls.

Energy consumption patterns in rental housing differ not only with building structure type but regionally as well. For instance, multifamily housing in the Northeast consumes more than twice the annual energy per unit consumed by similar housing in the West. Although there is less than one-third of the total multifamily (five or more units) rental housing stock in the Northeast, that region consumes almost $50 \%$ of all multifamily energy in the United States (Booz, Allen \& Hamilton 1979a, b). These higher energy use levels in the Northeast are the result of a combination of factors-building size, building age, and climate.

Table 3-1. ENERGY CONSUMPTION IN MULTTFAMLY UNITS (5 or More), 1974

\begin{tabular}{lccccc}
\hline & Northeast & North Central & South & West & Total \\
\hline \% Total units & 34 & 21 & 24 & 21 & 100 \\
\% Total energy consumed & 48 & 20 & 18 & 14 & 100 \\
Average consumption/unit & & & & & \\
$\left(10^{6} \mathrm{Btu}\right)$ & 141.1 & 95.2 & 75.4 & 69.1 & 100.7 \\
\hline
\end{tabular}

Source: Booz, Allen \& Hamilton 1979a,b.

Space heating (50\%) and domestic water heating (30\%) account for approximately $80 \%$ of the energy used in both the owner-occupied and rental sectors. These numbers vary slightly by region (slightly higher in the Northeast and North Central and slightly lower in the South and West) and by structure type. Conservation and solar applications are well suited for displacing nonrenewable energy resources for space heating and domestic water heating. 
The proportion of heating fuels used for space heating in both rental and owner-occupied dwellings is also fairly comparable. In both cases, natural gas, followed by fuel oil and electricity, is the most common energy source. The two most significant differences between renters and homeowners, as shown in Table 3-2, are: more renters (17.4\%) than owners (13.5\%) have electric space heating, and more renters (1.1\%) than owners $(0.4 \%)$ have no heating at all.

Table 3-2. RESIDENTIAL SPACE HEATING FUEL (\%)

\begin{tabular}{lcc}
\hline \multicolumn{1}{c}{ Fuel } & Owner & Renter \\
\hline Utility gas & $56.20 \%$ & $53.1 \%$ \\
Fliel nil & 20.40 & 21.5 \\
Electricity & 13.50 & 17.4 \\
LPG $^{\mathrm{a}}$ & 6.60 & 3.4 \\
Wood & 1.60 & 1.6 \\
Coal or coke & 0.60 & 0.7 \\
Kcrosene, etc. & 0.60 & 0.5 \\
Other (solar) & 0.03 & 0.5 \\
None & 0.40 & 1.1 \\
Total & $100.00^{\mathrm{b}}$ & 100.0 \\
\hline Source: U.S. Department of Commerce, \\
Bureau of the Census, Annual \\
Housing Survey 1977. \\
a Liquefied potroloum gas. \\
bColumn total rounded to 100\%.
\end{tabular}

Significant regional variation exists in the distribution of the four most common fuel sources for all residential space and water heating. The following tables and discussion are based on data gathered for the four leading energy sources and do not include wood, coal, kerosene, solar, or no heat, which together constitute about $4 \%$ of the total energy sources used by the rental housing sector. While both the West and the North Central regions predominantly use gas for space and water heating, the South uses about the same percentage of electricity as gas for space heating, and uses a higher percentage of electricity than gas for hot water. The units in the Northeast use more fuel oil than gas for space heating. These differences reflect relative regional fuel availability, and, in particular, the vulnerability of each area in the rental sector to present and future availability and costs of energy. Regional differences in fuel type used also reflect to some degree how economically attractive conservation and solar investments may be in particular regions. 
Table 3-3. RESIDENTIAL SPACE AND WATER HEATING FUEL SOURCES, BY REGION

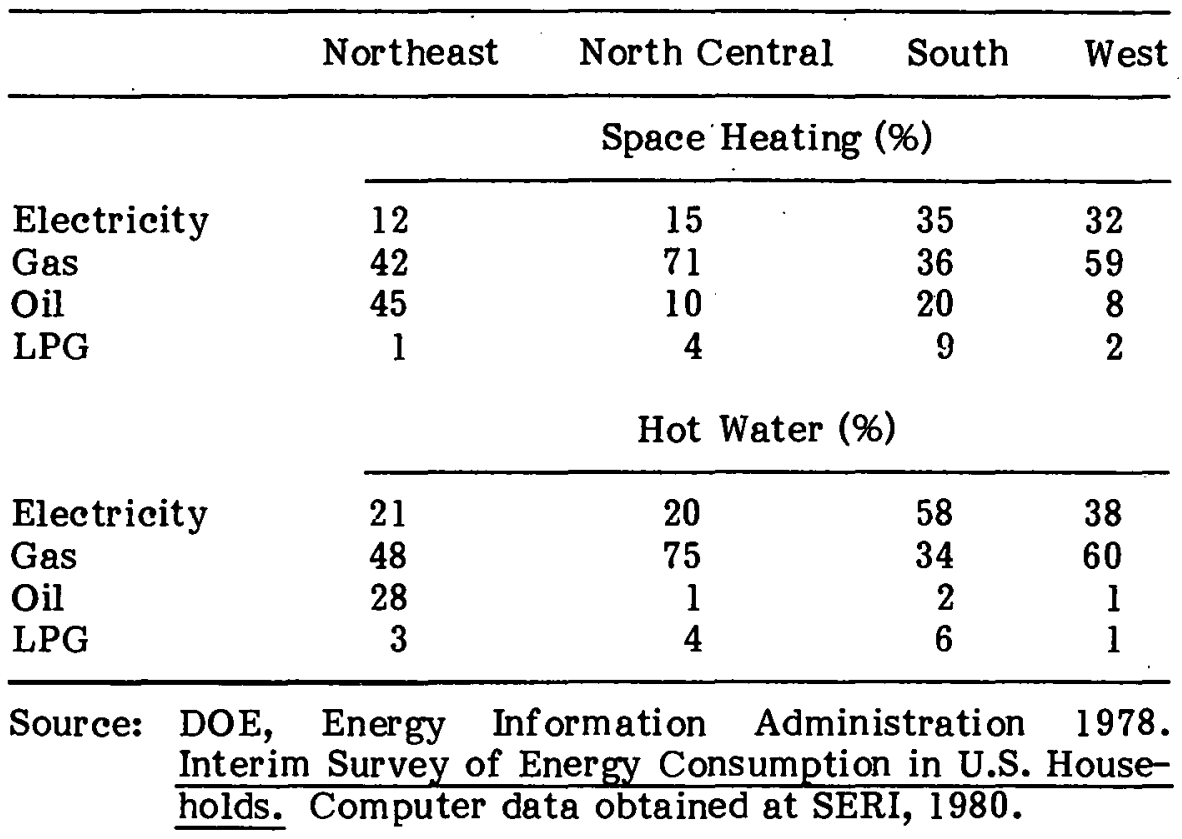

\subsection{WHO PAYS ENERGY BILLS?}

Many contend that when renters are responsible for their own utility bills, they have more incentive to conserve energy. But, as noted, there are substantial limitations to the amount of energy that tenants can conserve, because tenants face legal and economic barriers to making energy-related improvements to housing units they do not own. In master-metered rental buildings, it is clear that the building owner has a greater incentive to conserve energy or use solar energy in an attempt to reduce operating costs and improve the building's rate of return. In this section, we look at the proportion of separately metered and master-metered rental units as a basis for exploring the "energy relationship" between tenants and rental housing owners.

The percentages of space and water heating utility bills for all rental housing that are paid by the building owner and usually passed on to the tenant in the rent (mastermetered) as opposed to those paid directly by the tenant (separately metered) vary by fuel type, building structure, and region. In general, electricity is almost always paid directly by the renter, while fuel oil bills are of ten (especially for domestic hot water) paid by the owner and covered in the rent. Gas bills, on the other hand, while usually paid by the tenant, are paid by the owner more frequently than electricity bills.

The percentages presented in Table 3-4 reflect the type of system used to supply the delivered energy. While fuel oil for space and water heating is of ten used in centralized boilers, electricity usually is used directly in each dwelling unit. Gas, while sometimes used in centralized systems, is also used more of ten than fuel oil in individual systems for both single-family and multifamily dwellings. 
Table 3-4. HOW RENTAL UTLITY BILLS ARE PAID (\%)

\begin{tabular}{lccccccc}
\hline & \multicolumn{3}{c}{ Space Heat } & & \multicolumn{3}{c}{ Domestic Hot Water } \\
\cline { 2 - 4 } \cline { 7 - 9 } & $\begin{array}{c}\text { By } \\
\text { Tenant }\end{array}$ & $\begin{array}{c}\text { In } \\
\text { Rent }\end{array}$ & Other & & $\begin{array}{c}\text { By } \\
\text { Tenant }\end{array}$ & $\begin{array}{c}\text { In } \\
\text { Rent }\end{array}$ & Other \\
\hline Electricity & $95 \%$ & $5 \%$ & $1 \%$ & & $95 \%$ & $4 \%$ & $1 \%$ \\
Gas & 89 & 10 & 1 & & 88 & 11 & 1 \\
Fuel oil & 84 & 15 & 1 & & 59 & 39 & 2 \\
LPG & 97 & 2 & 1 & & 97 & 3 & - \\
\hline
\end{tabular}

Source: DOE, Energy Information Administration, 1978. Interim Survey of Energy Consumption in U.S. Households. Computer data obtained at SERI, 1980.

In Table 3-5, we see that the utility bill is almost always paid directly by the renter in single-family dwellings. In 2- to 4-unit structures, the gas and fuel oil bill is of ten paid by the renter in the rent, and fuel oil water heating is paid by the rental housing owner $60 \%$ of the time. Lastly, the energy costs are more likely to be incorporated in the rent in multifamily ( 5 or more) units than paid directly by the tenant for space and hot water heating when gas or fuel oil is used. Although electricity costs for space and water heating in multifamily housing are more often included in the rent than in single-unit or 2- to 4-unit housing, most of ten they are paid to the utility directly by the tenant.

Table 3-5 also shows that a higher percentage of electricity and fuel oil is used for space heating, and fuel oil for water heating, in large, multifamily units than in other rental housing. Moreover, almost $50 \%$ of the multifamily dwellings in New England use tankless water heaters, which heat water by running a loop through the space heating boiler (Bleviss 1980). This type of system requires that the boiler operate during the summer just to provide hot water.

It appears that the Northeast is the only region in the United States where a significant portion of energy costs are still paid by the rental property owner and passed on to the tenant as part of the rent. In about one-fourth of the rental buildings that use gas for space and water heating, the energy bills are paid by the owner; in about $30 \%$ of the cases, owners pay for space heating, and in about $45 \%$ they pay for water heating. These percentages reflect the relatively large number of high-rise apartments and centralized heating systems that exist in the Northeast. As Table 3-6 illustrates, in all other regions and for every fuel type nearly all space heating and water heating energy costs are paid directly by tenants. 
Table 3-5. HOW RENTAL UTHITY BILLS ARE PAI, BY STRUCTURE TYPE (\%)

\begin{tabular}{|c|c|c|c|c|c|c|c|c|}
\hline & $\begin{array}{c}\text { Space } \\
\text { Heating } \\
\text { Fuel Used }\end{array}$ & $\begin{array}{c}\text { By } \\
\text { Tenant }\end{array}$ & $\underset{\text { Rent }}{\text { In }}$ & Other & $\begin{array}{c}\text { Hot } \\
\text { Water } \\
\text { Heating } \\
\text { Fuel Used }\end{array}$ & $\underset{\text { Tenant }}{\text { By }}$ & $\underset{\text { Rent }}{\text { In }}$ & Other \\
\hline Single detached units & & & & & - & & & \\
\hline $\begin{array}{l}\text { Electricity } \\
\text { Gas } \\
\text { Fuel oil } \\
\text { LPG }\end{array}$ & $\begin{array}{l}23 \% \\
52 \\
20 \\
4\end{array}$ & $\begin{array}{l}99 \% \\
99 \\
99 \\
98\end{array}$ & $\begin{array}{l}1 \% \\
1 \\
1 \\
1\end{array}$ & $\begin{array}{l}1 \% \\
1 \\
1 \\
1\end{array}$ & $\begin{array}{l}37 \% \\
53 \\
5 \\
3\end{array}$ & $\begin{array}{l}99 \% \\
99 \\
98 \\
100\end{array}$ & $\begin{array}{l}1 \% \\
1 \\
2 \\
-\end{array}$ & $\begin{array}{l}1 \% \\
- \\
-\end{array}$ \\
\hline $2-4$ units & & & & & & & & \\
\hline $\begin{array}{l}\text { Electricity } \\
\text { Gas } \\
\text { Fuel oil } \\
\text { LPG }\end{array}$ & $\begin{array}{r}19 \\
60 \\
19 \\
2\end{array}$ & $\begin{array}{r}93 \\
69 \\
56 \\
100\end{array}$ & $\begin{array}{r}7 \\
28 \\
44 \\
-\end{array}$ & $\begin{array}{l}- \\
- \\
-\end{array}$ & $\begin{array}{r}23 \\
65 \\
11 \\
1\end{array}$ & $\begin{array}{r}89 \\
69 \\
40 \\
100\end{array}$ & $\begin{array}{l}10 \\
29 \\
60 \\
-\end{array}$ & $\begin{array}{l}1 \\
2 \\
- \\
-\end{array}$ \\
\hline \multicolumn{9}{|l|}{$5+$ units } \\
\hline $\begin{array}{l}\text { Electricity } \\
\text { Gas } \\
\text { Fuel oil } \\
\text { LPG }\end{array}$ & $\begin{array}{r}32 \\
46 \\
22 \\
1\end{array}$ & $\begin{array}{r}71 \\
47 \\
6 \\
50\end{array}$ & $\begin{array}{l}26 \\
49 \\
88 \\
50\end{array}$ & $\begin{array}{r}3 \\
4 \\
6 \\
-\end{array}$ & $\begin{array}{r}29 \\
50 \\
20 \\
1\end{array}$ & $\begin{array}{r}68 \\
43 \\
2 \\
20\end{array}$ & $\begin{array}{r}29 \\
-56 \\
91 \\
8\end{array}$ & $\begin{array}{l}3 \\
1 \\
7 \\
-\end{array}$ \\
\hline
\end{tabular}

Source: DOE, Energy Information Administration, 1978. Interim Survey of Energy Consumption in U.S. Households. Computer data obtained at SERI, 1980 . 
Table 3-6. HOW RENTAL UTILITY BILLS ARE PAID, BY REGION (\%)

\begin{tabular}{|c|c|c|c|c|c|c|c|c|}
\hline & $\begin{array}{c}\text { Space } \\
\text { Heating } \\
\text { Fuel Used }\end{array}$ & $\begin{array}{c}\text { By } \\
\text { Tenant }\end{array}$ & $\begin{array}{c}\text { In } \\
\text { Rent }\end{array}$ & Other & $\begin{array}{c}\text { Hot } \\
\text { Water } \\
\text { Heating } \\
\text { Fuel Used }\end{array}$ & $\begin{array}{c}\text { By } \\
\text { Tenant }\end{array}$ & $\begin{array}{c}\text { In } \\
\text { Rent }\end{array}$ & Other \\
\hline \multicolumn{9}{|l|}{ Northeast } \\
\hline Electricity & $12 \%$ & $91 \%$ & $9 \%$ & -- & $21 \%$ & $93 \%$ & $6 \%$ & $1 \%$ \\
\hline Gas & 42 & 76 & 23 & 1 & 48 & 79 & 20 & 1 \\
\hline Oil & 45 & 68 & 30 & 2 & 28 & 53 & 45 & 2 \\
\hline LPG & 1 & 83 & 17 & - & 3 & 94 & 4 & - \\
\hline \multicolumn{9}{|l|}{ North Central } \\
\hline Electricity & 15 & 99 & 1 & - & 20 & 97 & 3 & 1 \\
\hline Gas & 71 & 92 & 7 & 1 & 75 & 91 & 8 & 1 \\
\hline Oil & 10 & 98 & 2 & - & 1 & 100 & - & - \\
\hline LPG & 4 & 94 & 4 & 2 & 4 & 98 & 2 & - \\
\hline \multicolumn{9}{|l|}{ South } \\
\hline Electricity & 35 & 93 & 6 & 1 & 58 & 96 & 4 & 1 \\
\hline Gas & 36 & 94 & 5 & 1 & 34 & 90 & 9 & 1 \\
\hline Oil & 20 & 99 & 1 & 1 & 2 & 96 & 4 & - \\
\hline LPG & 9 & 99 & 1 & - & 6 & 96 & 4 & - \\
\hline \multicolumn{9}{|l|}{ West } \\
\hline Electricity & 32 & 96 & 2 & 2 & 38 & 95 & 3 & 2 \\
\hline Gas & 59 & 87 & 12 & 1 & 60 & 88 & 11 & 1 \\
\hline Oil & 8 & 98 & - & 2 & 1 & 100 & - & - \\
\hline LPG & 2 & 100 & - & - & 1 & 100 & - & - \\
\hline
\end{tabular}

Source: DOE, Energy Inf ormation Administration, 1978. Interim Survey of Energy Consumption in U.S. Households. Computer data obtained at SERI, 1980. 


\subsection{THE EFFECTS OF WHO PAYS ENERGY COSTS ON CONSERVATION AND SOLAR ENERGY INVESTMENTS}

Energy costs are either paid directly by tenants or paid indirectly in their rents. As shown, the majority of renters, especially in other than multifamily housing and in areas other than the Northeast, already pay their utility bills directly. However, in buildings where utility bills are still paid indirectly in rents, rapidly rising energy costs are making it increasingly difficult for rental housing owners to pass on $100 \%$ of their energy costs to tenants. One reason is that, in some cases in areas where the rental housing market is still somewhat competitive, owners know that rapid rent increases will render previously affordable housing unaffordable, thus increasing vacancy rates and decreasing profitability. A second restricting factor is rent control. Although most rent control districts have utility clauses which allow owners to pass on energy costs, completely transferring these costs is not always possible; it is usually more difficult to pass on utility costs to tenants in rent-controlled buildings. In general, because of rising energy costs, owners are facing increasing operating costs and decreasing profits. At the same time, tenants face higher rents and, in many cases, increased utility bills as well.

When the tenant is paying the utility bills, there is very little, if any, incentive for the owner to invest in conservation or solar energy equipment because owners see no immediate economic benefits. When an owner can readily pass on $100 \%$ of rising energy costs, there is likewise little incentive for investment. Landlords, then, have the greatest incentive to invest in conservation and solar energy when they pay energy bills themselves, or are unable to pass on total increased costs of utilities to tenants as part of the rent.

In cases where the local rental market is sufficiently competitive, an owner may gain a competitive edge by off ering units that have lower utility bills, or rents, or both. Eventually, conservation measures or solar energy use may also enhance a rental housing building's capital value. However, the current national rental housing market is tight, and rental housing's declining profitability is resulting in disinvestment. Incentives for energy-related improvements are not perceived to be sufficiently attractive to counterbalance other problems in the market.

\subsubsection{Separate Metering vs. Master Metering}

An option other than a conservation or solar energy investment for owners who are unable to pass on all increasing energy costs indirectly is to switch from master metering to separate metering. From the owner's perspective, this can be a money-saving investment which succecds in passing on energy costs directly where owners can no longer pass them on adequately in an indirect manner through rent increases. In many states, separate metering is viewed as a conservation technique that forces tenants to be more responsible for their energy consumption habits. In fact, a Booz, Allen \& Hamilton study $(1979 \mathrm{~b}, \mathrm{p} . \mathrm{l})$ estimates that switching to separate metering can cause tenants to use from $15 \%$ to $20 \%$ less electricity and $3 \%$ to $8 \%$ less natural gas. Many tenants view separate metering as a way to stop subsidizing some of their more energy-wasteful neighbors. Although this transition is becoming more popular in multifamily housing, it remains highly controversial. While potentially significant energy savings can be attained by separate metering and subsequent tenant conservation actions, switching to separate metering decreases the owners' incentive to invest in conservation or solar devices. 
A second problem accompanying a switch to separate metering is that such a change often means a change from fuel oil or natural gas to electricity-which is cheaper to install and more readily adapted to separate metering, however, more expensive to use. Electricity for space heating is not only being used in multifamily rental retrofits, but over half of all new single-family housing built between 1977 and 1979 uses electric space heating as the primary heating source (Stoll 1980). Not only will conversion to electric space heating raise tenants' heating costs because of the higher relative cost of electricity, but the relatively less efficient use of electricity for space heating squanders society's precious fossil fuel reserves as it increases consumption of primary, nonrenewable fuels.

Finally, switching to separate metering in multifamily rentals for all energy systems may necessitate abandoning central domestic water and space heating systems, In both cases, a central system is generally more energy efficient; therefore, an increase in net energy use increase may occur. Furthermore, central water heating is an ideal solar application, and an abandonment of central water heating can forfeit important potential solar energy benefits.

While there is a growing trend among state public utility commissions simply to ban master metering in new construction, no consensus yet exists (Table 3-7). It is critical that policy makers fully understand the potentially adverse long-term effects on energy conservation and solar energy use that could be caused by a ban on master metering. Without coupling a ban on master metering with programs and incentives to guarantee that either concurrent or future conservation and solar energy measures will be undertaken, removing what little incentive still remains for owners to invest in energy-saving devices may exacerbate the energy situation in the rental sector.

Table 3-7. MASTER METERING IN NEW CONSTRUCTION (STATE PUBLIC UTIITY COMMISSIONS)

\begin{tabular}{lr}
\hline No law & $57 \%$ \\
Banned & $14 \%$ \\
Electricity banned only & $14 \%$ \\
Allowed & $8 \%$ \\
Discouraged & $8 \%$ \\
\hline
\end{tabular}

Source: Booz, Allen \& Hamilton 1979 b, p. 6.

\subsubsection{Rent Control}

While rent control programs were originally instituted to protect tenants from rapidly rising rents in tight rental housing markets, today they generally discourage owners from investing in conservation and solar energy devices. Although most rent-control laws have fuel escalator provisions, allowing owners to pass on rising energy costs to tenants through rent increases, there are few rent-control boards that allow owners to pass on conservation costs. Furthermore, owners in many areas are required to lower rents if the utility costs decrease because of conservation measures taken by the owner. Under rent control, owners who want to invest in energy conservation or solar energy usually must 
bear the full cost themselves; therefore, they have little incentive to make such investments.

In the face of tremendous increases in operating expenses in general and fuel costs in particular, a building owner has few remaining options for maintaining the financial viability of the rental housing building. If the owner is prevented from passing the cost of conservation measures or solar energy equipment to tenants because of rent control, the options are further limited, and the result may further tighten the rental market through condominium conversion and abandonment.

A few rent-control boards-one in Cambridge, Massachusetts, for example-have clauses in the regulations that allow owners to pass on the full cost of conservation devices. Although such programs are one step toward conserving fuel use in rental housing, passing on conservation expenses to tenants could result in higher rents, including utility payments, than if no conservation devices had been installed. It is crucial, therefore, that escalator clauses be designed to regulate carefully the proportion of each investment that can be passed on to tenants and the rate at which the cost of the investment is charged back to tenants.

\subsection{THE POTENTIAL FOR TENANTS TO INVEST}

Since most tenants in rental housing pay their utility bills directly, why don't tenants themselves invest in conservation and solar energy? For small investments with payback periods shorter than a lease or for portable devices such as low-flow shower heads that the renter can take when moving, tenants' investments are reasonable. However, these strategies are subject to restrictions. First, certain legal restraints can prevent tenants from changing or tampering with rented property without the owner's permission. Although owner/tenant cooperation is possible, more expensive, substantial investmentssuch as insulation or a solar water heater-could meet with greater resistance from property owners.

In addition to legal constraints, there are often economic barriers. As noted in Sec. 2.5, renters generally have less disposable income than homeowners or rental housing owners to invest in conservation or solar energy. Furthermore, since renters usually occupy a building an average of less than three years, it is difficult for them to realize an economic payback on many energy-saving expenditures. Lastly, the relationship between owners and tenants has been traditionally one in which tenants expect property improve- . ments to be made by owners.

\subsection{SUMMARY: ENERGY USE IN THE RENTAL SECTOR}

The dynamics of the relationship between owners and tenants regarding energy expenditures in general and conservation and solar investments in particular sets apart the rental sector from the residential sector as a whole. In the rental sector, those who absorb the majority of energy costs are not the same as those who make conservation or solar energy investment decisions. And, where the owners of master-metered buildings can remove themselves from utility expenses even further through conversions to separate metering or passing on energy costs in rents, there is very little incentive for those owners to invest in conservation or solar energy. At the same time, tenants lack both financial and legal means to make energy-related improvements themselves. As a result, minimal conservation or solar investments can be expected in the rental sector without 
policies and programs that are sensitive to the dynamics of the owner/tenant relationship. These programs must focus on rental housing owners. The following section explains how rental housing owners evaluate investments, and how they can be most eff ectively encouraged to invest in improvements in energy efficiency. 


\section{SECTION 4.0}

\section{INVESTMENT CRITERIA OF RENTAL HOUSING OWNERS}

As noted in Sec. 3.0, the majority of rental housing in the United States is separately metered. This arrangement exacerbates the problems of energy inefficiency in rental housing since owners of master-metered buildings have a greater potential incentive to invest in conservation or solar energy. This section applies best to the minority of rental housing units that are master metered, and it has particular relevance to regions or localities with a predominance of master-metered rental housing.

However, this section is also relevant for owners of separately metered buildings for two major reasons. First, owners of separately metered buildings must pay the utility costs for common space, and conservation and/or solar energy devices may enhance profitability. Second, owners of separately metered buildings must consider tenants' ability to pay both utility bills and rent, because tenants are more likely to put off rent payments than utility payments. Therefore, the information presented here on owners' investment decision criteria can be useful for evaluating energy policies for rental housing.

Although a large portion of rising energy costs are passed to tenants, residential rental building owners are of ten constrained in passing on the total increased cost of energy to renters. Rising energy costs are causing operating costs to rise, and this, in turn, decreases the profits to be made from residential rental property. The U.S. General Accounting Office (GAO) reports that increased operating costs are one factor leading to increasing reliance on the Federal Government to provide rental housing. In 1980 it is estimated that about $75 \%$ of multifamily rental housing starts will be federally subsidized and/or insured (GAO 1979, p. 25). The small percentage of rental housing starts financed wholly by the private sector indicates declining profit potential for investments in rental housing.

This section describes how rental housing owners make investment decisions in general and for energy-related invesments in particular. There are ways that the incentives mentioned here can increase profitability most easily for owners of master-metered rental housing, but also for owners of rental housing that is separately metered.

\subsection{DECLINING PROFITABILITY IN THE RENTAL HOUSING MARKET-OWNERS' RESPONSES}

Operating costs for building owners and managers are increasing more rapidly than are revenues collected in rents. In a study for HUD, Touche, Ross and Company reported that, since 1970, fuel and utility expenses have increased $98 \%$ in apartment buildings while rents have increased only 39\% (Booz, Allen \& Hamilton¹979a. See also Fig. 4-1.).

Rental housing owners are reacting to declining profit potential in a number of ways. As mentioned in Sec. 3.0, building owners or managers will pass the increasing costs of energy on to tenants when possible. There are cases, however, where rent control regulations or tenants' inability to pay rents high enough to cover fuel costs make it impossible for the owner to pass those costs along, according to Aimee Gemeiner (1980). 


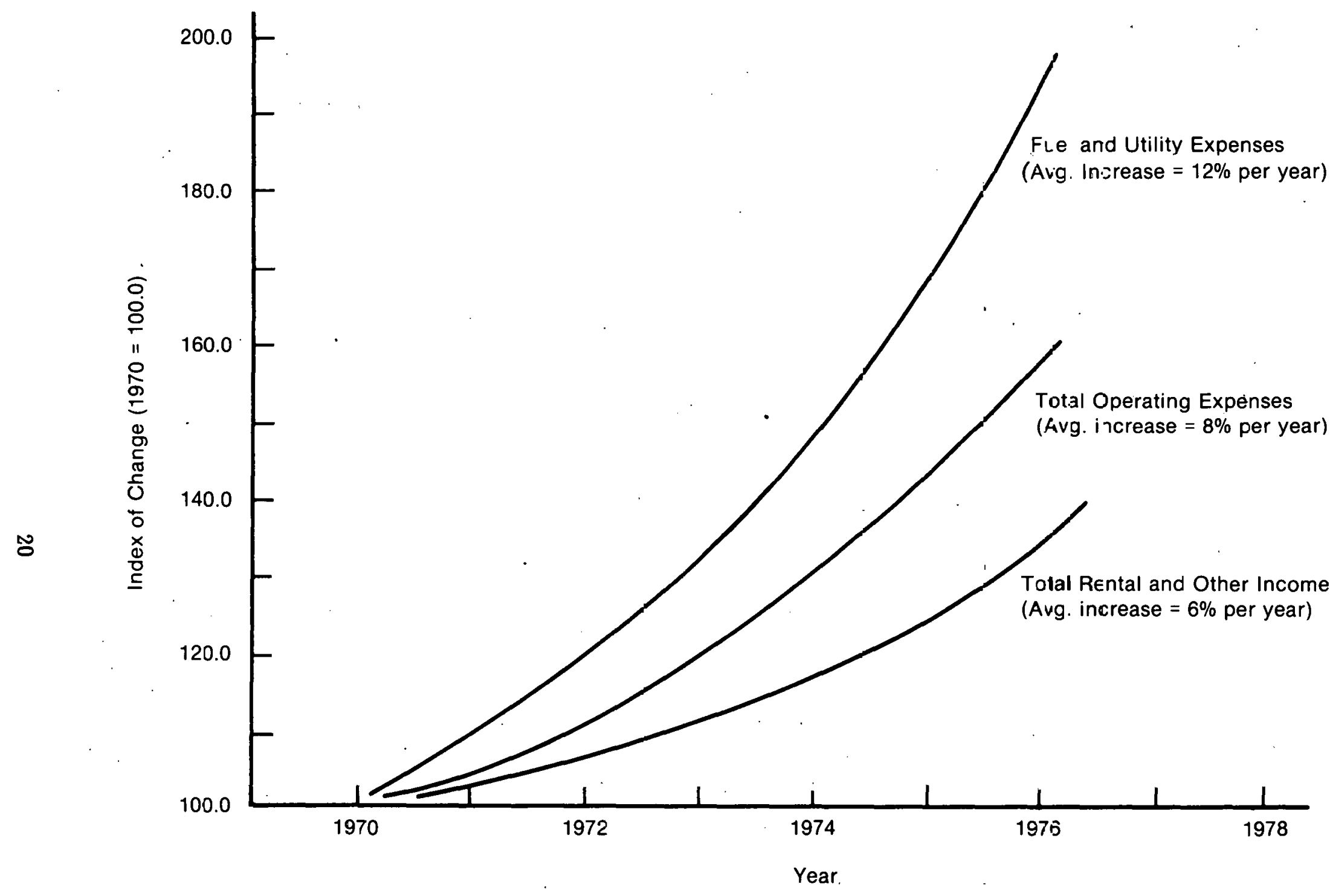

Figure 4-1. Change in Operating Revenues and Expenses for 189 Apartment Building Properties: 1970-1976

Source: Touche, Ross \& Company.

From: Booz, Allen \& Hamilion. May 1979. Achieving Energy Conservation in Existing Apartment Buildings. Appendix D. 
In a number of cases, building owners and managers are changing master-metered rental units to separate utility metering. Disadvantages of this strategy were detailed in Sec. 3.0. Another approach to combating lower profits from rental property is for the owner to convert the property to condominiums. While total conversions in the United States represent only $1.3 \%$ of the housing stock (HUD 1980), there are particular cities and neighborhoods within cities where rental housing stock has been severely limited by condominium conversion. In some urban neighborhoods, conversion has been occurring at rates as high as $20 \%$ and $30 \%$ (HUD 1980). Although renters may become owners of their units through condominium conversion, the General Accounting Office (GAO) reports that, of the $56 \%$ of the sample rental units in its study that low-and moderate-income households could afford before conversion, those households could afford only $12 \%$ of those units after conversion (GAO 1979, p. 19). Evidently, when building owners respond to rising energy costs by converting rental units to condominiums, the shortage of rental housing available for low- and moderate-income households increases. This problem is likely to grow, since HUD estimates there will be 1.1 million more condominium conversions (4.5\% of the housing stock) by 1985 .

Abandoning the building is the ultimate response of a building owner to increased operating costs. The GAO reports that accurate and reliable information about abandonments is not generally available. However, as GAO cites:

A January 1979 report on a HUD-commissioned survey of abandonment in 230 declining U.S. cities reported observable levels of abandonment in 150 of the cities during 1978 . A total of 259,505 dwelling units were reported to be abandoned in the 150 cities, of which about 186,000 (or $71.7 \%$ ) were multifamily units. (GAO 1979, p. 20)

In Springfield, Massachusetts, as many as $25 \%$ of the buildings in their low-income areas face the possibility of abandonment because of rising energy costs alone (Bleviss 1980). Abandonment, like condominium conversion, removes rental units from the housing market, making a tight market even tighter. However, unlike condominium conversion, abandonment occurs most often in low-income rental housing. It appears that rising energy costs are a major culprit in the abandonment problem. However, few relevant statistics are currently available.

\subsection{INVESTMENT DECISIOON CRITERIA}

It is clear that owners and managers of residential rental property are facing difficult decisions arising because of the increased costs of conventional fuels. It is important also to understand the decision calculus that motivates building owners, managers, and investors in rental housing. Only by looking carefully at how investment decisions are made for income property can policy makers influence decision-making behavior. This section outlines factors contributing to an investment decision for existing property and suggests steps that may spur investments in retrofit conservation and solar energy equipment by investors, owners, and managers of rental housing.

\subsubsection{Types of Profit and Forms of Ownership}

Three types of profit can be earned in operating rental housing. First, a positive cash flow gives an annual operating income to the owner. Second, if the property appreciates in value over time, the owner or investor may make a capital gain at the time of the 
building's sale. Third, tax effects such as depreciation allowances and operating expense deductions can reduce an owner's or investor's income tax liability.

In addition to the three types of profit, there are a variety of ownership forms for real estate. These include:

- proprietorship:

- general partnership:

- limited partnership:

- corporation: a single owner;

two or more owners with assigned gains and losses;

two or more owners, including both general partners who make decisions and limited partners who are passive investors (a popular form of ownership for low- and moderate income rental housing, as limited pur'tners ure passive investors reaping the benefits of tax write $=$ off $\varepsilon$ for depreciation and expenses); and

a formal ownership arrangement where the corporation is an entity separate from the owners, limiting ownore' liabilities.

There are advantages and disadvantages to each form of ownership. Investors and building owners select the form of ownership most profitable for them based on their existing assets, tax liabilities, and general portfolios. Individual investors or building owners will also have preferences for the most beneficial type of profit, given their particular financial situations. Form of ownership and type of profit interact, and individuals investing in or owning rental housing will select a combination most beneficial and profitable for them.

As illustrated in Fig. 4-2, $81 \%$ of all occupied multifamily rental units are privately owned. Of these, $28 \%$ receive federal financial assistance. Most of these units are for low- or moderate-income tenants, and all are constructed by private developers. The most popular form of financing for this type of multifamily housing is the limited partnership. The primary form of profit for limited partners is tax benefits that accrue mainly from depreciation allowances and business expense deductions. Accelerated depreciation is allowed by the Internal Revenue Service for low- and moderate-income rental housing property.

Of the privately owned rental units in buildings of five or more units, $72 \%$ are privately financed. Of this total, the majority (70\%) are owned by individuals who are likely to be seeking all three types of profit-annual income from a positive cash flow, capital gains on the building's value, and tax benefits from depreciation and expense deductions. Corporations and partnerships own $24 \%$ of the privately owned, privately financed rental units. Corporations and partnerships are likely to seek tax benefits as the most useful type of profit. However, they are also interested in maintaining a positive cash flow in order to maintain the building's value, since value is based on income as well as tax benefits and projected gains. The remaining $6 \%$ of privately financed, privately owned rental units may be owned by business trusts, real estate investment trusts, or various other forms. Because this represents a small number, these forms of ownership will not be discussed here (see Fig. 4-2). Rental housing in buildings with one to four units is more likely to be owned by individuals who have less capital to invest. However, supporting data are unavailable. 


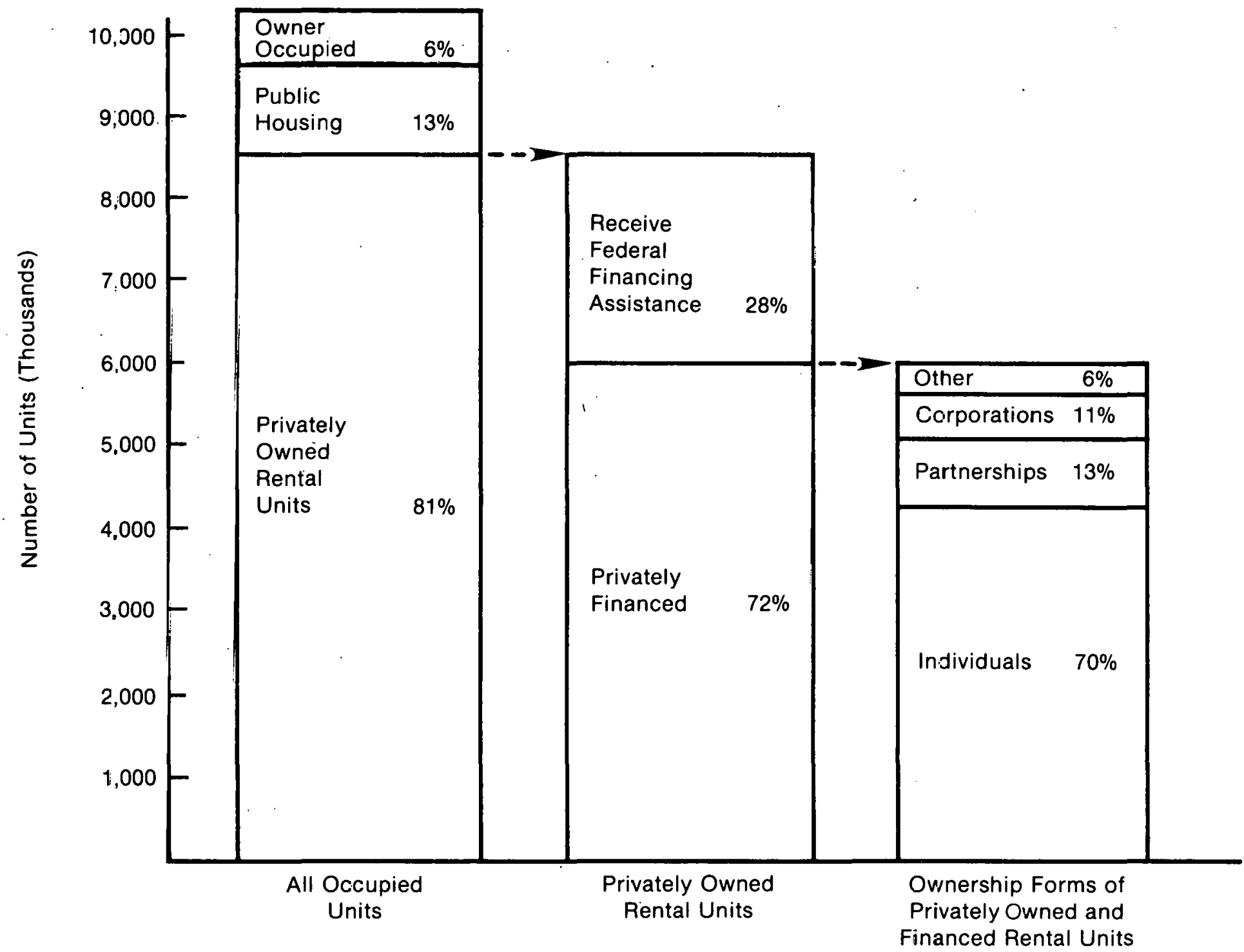

Figure 4-2. Breakdown of Apartment Ownership Forms - 1976

Sources: Annual Housing Survey 1976, U.S. Department of Commerce, U.S. Department of Housing and Urban Dévelopment, and Booz, Allen \& Hamilton Estimates.

From: Booz Allen \& Hamilton 1979. 
Policies and programs designed to encourage conservation and solar energy investments must take into account owners' preferences for types of profit and how they calculate returns on such investments.

\subsubsection{The Investment Decision Calculus}

There are basic calculations that building owners, investors, and managers make when deciding whether to make a capital investment in a residential rental building. Understanding these calculations helps policy makers predict how various incentives will affect a rental housing owner's profits.

\subsubsection{Cash Flow}

The basic calculation used by building owners, investors, and managers to calculate the annual operating income or cash flow is called the "set-up."

\begin{tabular}{|c|c|}
\hline & $\begin{array}{l}\text { Gross rent } \\
\text { vacancy }\end{array}$ \\
\hline & $\begin{array}{l}\text { Effective gross rent } \\
\text { operuling expenses } \\
\text { real estate taxes }\end{array}$ \\
\hline & $\begin{array}{l}\text { Free and clear cash flow } \\
\text { debt service }\end{array}$ \\
\hline & $\begin{array}{l}\text { Before-tax cash flow } \\
\text { income tax effects }\end{array}$ \\
\hline
\end{tabular}

Gross rent is the total of all rents charged. Vacancy represents losses from vacant units and is calculated by multiplying a historically based vacancy rate by the gross rent. The gross rent minus vacancy losses is equal to the effective gross rent. Operating expenses include utility charges, maintenance. and repair, a replacem ent fund for major items such as a furnace, insurance, and (sometimes) a management fee. Real estate taxes and operating expenses are subtracted from the effective gross rent to obtain the free and clear cash flow, or annual income of the property. The free and clear figure is also used by assessors and bankers to calculate the value of a building, and therefore, the likely capital gain to be made on the investment when the building is sold. While in some cases.the tax deduction allowed for loss from a negative free and clear cash flow may be beneficial to the owner, it is important to most owners to maintain the capital value of the building. This is also important to state and local property tax revenues.

From the free and clear cash flow, the owner or investor subtracts debt service (the amount of mortgage payments), to arrive at a before-tax cash flow. In order to maximize the free and clear cash flow, owners try to keep operating expenses, real estate taxes, and debt service to a minimum. Subtracting tax effects yields an after-tax cash flow. 
Rising energy costs increase operating expenses and tend to diminish the free and clear cash flow. An investment in conservation and solar energy equipment may reduce utility expenditures. However, part of the problem in convincing owners to make energyrelated investments is that the resulting amount of savings is hard to predict. Owners may be unsure about how many Btu can be saved, and they may be unsure about the magnitude and timing of increases in conventional fuel prices. The uncertainty involved in calculating the cost-effectiveness of an investment in conservation or solar energy has proven a major barrier to such investments in multifamily rental housing (Booz; Allen \& Hamilton 1979). Although the Booz, Allen \& Hamilton report is only one example, and it appears that general improvements in rental housing are on the decline, rental housing owners would be likely to invest in energy-related improvements if they could be sure that such an investment would improve their financial positions.

If a rental housing owner is able to calculate a conservation or solar energy investment's contribution to utility expense savings, that savings must be weighed against the cost of the investment. The initial cost of conservation or solar energy equipment can only be recouped over time through savings in utility expenses, if the investment increases property value for future capital gain, or by way of other benefits most likely to accrue over time. Financing schemes that allow owners to pay for investments over time as they realize savings can make an investment in conservation or solar energy equipment more attractive, easier to pay for in a capital-short market, and could actually make it possible for owners to invest without raising rents at all.

A higher mortgage and lower equity investment can be an immediate benefit in the form of tax deductions for the interest portion of the mortgage. In a workshop conducted for developers of commercial office space, a $1 / 2 \%$ break on the mortgage was a substantial incentive, more significant to the developers than an increase in the federal tax credit from $25 \%$ to $45 \%$ (presuming no performance uncertainty) (Sussman 1980). An additional option for solar energy systems is a leasing arrangement. If the annual payment for the conservation or solar energy system, whether through an ownership or lease payment, is less than or equal to projected utility expenses, the gross rent can remain at the same level.

In calculating the total annual cost of an investment, three other factors must be considered. First, if the owner spends less for conventional fuel, expense deductions from income tax liability will be lower, increasing that tax liability. However, building owners are allowed a $15 \%$ nonrefundable income tax credit for renewable energy-related investments (see Sec. 5.1.1). Some states have an additional income tax credit for solar and/or conservation investments. In addition, owners are allowed to deduct interest payments from income tax liability. However, if an investment in conservation or solar energy increases property value, property taxes may increase. State and local governments can counter this disincentive by exempting conservation and solar energy improvements from property taxes.

To perform a financial analysis, it is not enough to arrive at an after-tax cash flow that equals or exceeds the after-tax cash flow before an investment. Building owners compare investments, seeking maximum returns on money invested. According to a survey conducted by the National Apartment Association (NAA), owners of apartment buildings with five or more units were requiring savings in fuel bills sufficient to allow them to pay off any conservation investment in three years (Booz, Allen \& Hamilton 1979a). This is approximately equivalent to a $33 \%$ return on investment, which appears excessive because other investments in energy equipment are unlikely to earn such a high rate of return. We can only assume that the high rate required is due in part to the uncertainty 
accompanying predicted savings from a conservation investment. Whatever the cause, the high required return makes it difficult to persuade building owners to invest in conservation or solar energy. Even if the required rate of return were lower, it is important to remember that investments in conservation and solar energy are not compared only with conventional fuel and heating equipment, but also with a world of investment opportunities, all with varying rates of return.

\subsubsection{Capital Gain}

One important feature of the free and clear cash flow is that the value of the property is based primarily on its free and clear cash flow, or net profit. Therefore, it is important to maintain or increase a property's net profit to maintain or increase that property's value.

One method to calculate a building's value is to divide annual income by a capitalization rate. The capitalization rate is subjectively determined, but usually is equal to the going rate for borrowing money plus percentage points added for risk. If the investment in a particular rental building is deemed safe, the capitalization rate will be relatively low, and the building's value will be relatively high. If an investment in property is deemed risky, the capitalization rate will be higher and the value lower.

To maximize the profit from capital gain at the time of sale, it is necessary to maximize the free and clear cash flow. Reducing utility expenses through an investment in conservation or solar energy can increase the cash flow as long as the savings exceed the cost of the investment. Again, this provides a good argument either for financing schemes or leasing arrangements that allow owners to pay for conservation and solar energy equipment over time. Spreading payments over time reduces the building owner's need to raise rents to cover conservation and energy-related expenses.

Because capital gains depend heavily on the property's annual income or cash flow, owners interested in maximizing profit through capital gain face the same type of difficulty associated with cash flow; that is, the uncertainty accompanying efforts to determine the cost-effectiveness of a conservation or solar energy investment.

\subsubsection{Tax Benefits}

Tax benefits are the major source of profits for all forms of ownership, and they are especially important to limited partnerships because limited partners' profits are of ten restricted to beneficial tax effects. Tax benefits have special implications for investments in conservation and solar energy for low- and moderate-income housing because limited partnerships are the most popular form of ownership for such housing.

Tax benefits include:

- income tax liability credits for operating expenses, including conventional fuel expenses;

- deductions for the interest portion of payments for capital equipment and real property; and

- accelerated or conventional depreciation, allowing owners to deduct a fixed portion of the building's value from income tax liability over a scheduled period of time. 
Each of these categories holds implications for energy. The ability to deduct operating expenses may have a negative impact on a building owner's decision to invest in conservation or solar energy. Reduced fuel expenses mean reduced tax write-offs. One method for eliminating this disincentive is to exempt fuel expenses from allowable deductions. However, because of the general declining profitability of rental housing, such a step could further exacerbate the problems in the market.

If owners invest in conservation or solar energy and can finance the investment over time, they may deduct the interest portion of the payments from income tax liability. If there is an opportunity to lease conservation equipment or a solar energy system, lease payments would be allowed as operating expense deductions.

Accelerated depreciation is a major tax deduction and contributes significantly to overall profit in rental housing. An added incentive to investments in conservation and solar energy would be to allow accelerated depreciation on conservation and solar energy equipment. An alternative would be to allow building owners to add the value of the investment to the building's existing depreciation schedule at the time of retrofit.

\subsubsection{Preferred Incentives}

To be most effective, financial incentives should be of the type preferred by rental housing owners. Booz, Allen \& Hamilton (1979a) report that a National Apartment Association survey of multifamily rental housing owners (five or more units per building) indicated a strong preference for tax credits and a strong dislike for loan guarantees and grants. Although owners of smaller buildings or fewer buildings may welcome grants or loan guarantees, in almost every form of ownership, a substantial portion of profits from owning rental property is in the form of tax benefits. Rental property owners are, therefore, familiar with the tax system, and it is not surprising that many would prefer incentives in the form of tax credits over loan guarantees or grants which require greater government involvement in their operations. It appears also that financing programs offering reduced interest rates may be effective incentives to investments in solar and/or conservation equipment. The strength of this incentive requires further analysis, however.

Because the majority (72\%) of owners surveyed indicated they would make an investment if the payback period were three years or less, this is a serious barrier to some conservation and most solar energy investments because payback periods are generally longer than three years. When conservation and solar energy investments are evaluated on a life-cycle cost basis, they are often competitive with conventional fuels and appear to be sound investments. However, if owners have a maximum three-year payback period requirement, it would be difficult for them to perceive such an investment as costeffective or financially sound. Providing incentives that would assure a three-year payback would be difficult if not impossible to design and extremely expensive for government to carry out.

Finally, apartment owners have little basis on which to judge and calculate the costeffectiveness of an investment because they are unsure about how much conventional fuel they will save or the future value of that fuel. 


\subsection{SUMMARY: OWNERS' INVESTMENT DECISTONS CRITERIA}

In operating rental housing, revenues minus expenditures equals profits. The building's value is usually based on this calculation.

There are three types of profit and a variety of forms of ownership. Investment decisions are based on maximizing total return to investors, using the most beneficial form of ownership and pursuing the most rewarding type of profit.

The three major categories of expenses are debt service, taxes (federal income tax, capital gains tax, state income tax, and local real estate taxes), and operating costs. Building owners and managers try to minimize all three categories of expenses in order to maximize profit.

Operating costs can be reduced by making investments in equipment that enhances a building's energy efficiency. But that equipment requires capital expenditures that will have attendant tax effects. Energy-related investment costs can be offset by financing schemes that spread the capital expenditure over time, by leasing arrangements for solar energy, and by tax credits and accelerated depreciation allowances for owned systems. However, a major barrier is that owners are unsure of the value of potential savings from a conservation or solar energy investment.

We have suggested two incentives that are likely to induce profit-seeking rental housing owners to invest in energy conservation or solar energy equipment-incentives that will encourage an investment while possibly obviating the need for higher rents. First, financing energy equipment investments with a low down payment (reducing up-front capital required) and annual payments lower than projected energy savings would not reduce rental property owners' profit and, in fact, may enhance it. It is important that such a financing package be assumable in the case of building sale. For solar energy systems, leasing programs with annual payments lower than projected conventional utility expenses serve a similar purpose.

The second type of incentives are tax incentives. Accelerated depreciation allowances on energy equipment could substantially decrease the income tax liability of rental housing owners and investors. Since $81 \%$ of multif amily rental housing is owned privately, a substantial number of owners and investors are likely to be seeking tax benefits in the form of reduced income tax liability. Another tax incentive would be to make energy equipment not liable to property tax assessment until the building is sold. Again, this would reduce taxes, a major expense category for building owners.

Even with such incentives, however, important limitations still exist. First, owners who can actually increase their rates of return through investments in conservation and solar energy lack information about how to calculate cost-effectiveness. Contributing to this problem are uncertainties about potential fuel savings and the future value of those savings, making it more difficult for owners to assess an investment's cost-effectiveness. Second, owners are likely to evaluate an investment on the basis of a rate of return or payback period rather than with a life-cycle cost analysis. Owners' investment criteria make investments in conservation and solar energy appear unfavorable, especially because they almost invariably compare such an investment to other non-energy-related investments where the rate of return may be higher. Finally, and most importantly, an economic disincentive is created when owners either do not pay utility costs directly, or they are able to pass on energy costs to tenants in the rent. 


\section{SECTION 5.0}

\section{FEDERAL, STATE, AND LOCAL INVESTMENT INCENTIVE PROGRAMS}

Since owners of rental housing tend to make investment decisions on the basis of rates of return or payback period, owners will try to minimize operating costs to maximize these returns. Thus, policies aimed at encouraging investments in conservation and solar energy equipment for rental housing will be most effective if they address owners' concerns about overall returns from rental housing operations in general rather than merely specific payback periods on the conservation or solar energy equipment.

\subsection{PEDERAL PROGRAMS}

In this section, we describe federal programs intended to encourage investments that will make rental housing more energy efficient. It appears that federal programs have not been effective toward this end. The reasons for this become clear when these programs and policies are analyzed in light of the rental housing owner's investment decision process.

\subsubsection{The Energy Tax Act}

To encourage investment in solar energy equipment for the entire residential sector, the Energy Tax Act of the National Energy Act of 1978 provided a nonrefundable $30 \%$ income tax credit for the first $\$ 2,000$ spent on solar energy equipment and $20 \%$ for the next $\$ 8,000$. In April 1980, the energy tax credits section of the Windfall Profits Act increased the tax credit available for residential solar, wind, and geothermal equipment to $40 \%$ on the first $\$ 10,000$ expended. In addition, a $15 \%$ tax credit is allowed for conservation expenditures for both homeowners and renters. These credits are available for taxpayers making investments on their principal residences. While the credit is available to tenants, both legal and financial constraints upon tenants make it almost impossible for them to take advantage of the credit. The tax credit applies to owners who occupy a unit in their rental property. However, since the credit could be used only for energy investments in the owner's particular unit and not in the entire structure, the credit will have no effect on most rental units.

Although rental housing owners are ineligible for any federal income tax credit for conservation, they are eligible for a $15 \%$ energy investment tax credit for renewable energy improvements made in the rental property, according to the Windfall Profits Act. Though the $15 \%$ tax credit does reduce income tax liability and will, therefore, increase the rate of return from an energy-related investment, the credit is probably too low to overcome the many barriers discussed in the section on owners' decision-making criteria. The lower solar tax credit for rental housing owners and the lack of a tax credit for conservation demonstrate the general federal energy policy blas towurd uwileroccupied residential buildings.

\subsubsection{The Solar Energy and Energy Conservation Development Bank}

The Omnibus Energy Bill (S 932) that established the synthetic fuels program also established a Solar Energy and Energy Conservation Development Bank. This bank will be run 
by the U.S. Department of Housing and Urban Development (HUD) and will provide federally subsidized loans for installing conservation and solar energy equipment in residential and commercial buildings. Subsidies will be offered on a sliding scale based on the applicant's income. Regulations should be final and loan money available by spring 1981. Loan subsidy rates have not been established. Interest rates will be set by participating banks.

\subsubsection{Conservation}

Households, including renters, with incomes below $80 \%$ of an area's median income will be eligible for a subsidy on $50 \%$ of the cost of their conservation improvements. Households with incomes between $80 \%$ and $120 \%$ of an area's median income may subsidize $15 \%$ of the first $\$ 700$ of conservation expenditures and $30 \%$ of the balance to the maximum amount allowable, as shown in Table 5-1.

Table 5-1. MAXIMUM SUBSIDIES ALLOWED FOR CONEERVATION EXPENDITURES BY THE SOLAR ENERGY AND ENERGY CONSERVATION DEVELOPMENT BANK (Proposed)

\begin{tabular}{ccc}
\hline No. of Units & $\begin{array}{c}80 \% \text { Median Income } \\
\text { Amt./Unit }\end{array}$ & $\begin{array}{c}80 \%-120 \% \text { Median Income } \\
\text { Amt./Unit }\end{array}$ \\
\hline 1 & $\$ 1,250$ & $\$ 750$ \\
2 & 1,000 & 600 \\
3 & 916 & 550 \\
4 & 875 & 525 \\
$5+$ & 400 & 400 \\
\hline
\end{tabular}

For multifamily buildings, owners will be eligible for subsidies regardless of their incomes. The subsidy level will equal $20 \%$ of the cost of conservation improvements or $\$ 400$ per unit, whichever is lower.

\subsubsection{Solar Energy}

Subsidies for passive or active solar retrofits will depend both on the applicant's income and the amount of energy saved. Formulas for calculating subsidies will be in regulations now under preparation at HUD. For passive solar retrofits, there will be no income limit for subsidy eligibility. For active solar installations, only households with incomes below $80 \%$ of the area's median income will be eligible for subsidies on $60 \%$ of the system's cost. However, these proposed regulations are for buildings with 1 to 4 units only. Regulations for multifamily ( 5 or more) units are not yet available. Proposed maximum subsidy amounts are presented in Table 5-2. 
Table 5-2. MAXIMUM SUBSIDIES

ALLOWED FOR SOLAR

ENERGY EXPENDITURES

BY THE SOLAR ENERGY

AND ENERGY CONSERVA-

TION DEVELOPMENT

BANK (Proposed)

\begin{tabular}{cc}
\hline No. of Units & Maximum Subsidy per Unit \\
\hline 1 & $\$ 5,000$ \\
2 & 7,500 \\
3 & 10,000 \\
4 & 10,000 \\
$5+$ & 2,500 \\
\hline
\end{tabular}

Alone, these subsidies may be too low to convince the majority of rental housing owners to make investments in conservation and solar energy equipment, presuming their eligibility for solar energy loan subsidies. But for those who have been considering such an investment, a Solar Bank subsidy may provide the deciding incentive that makes an investment profitable. It should be noted, however, that if rental housing owners are eligible, the portion of the solar energy loan that is subsidized will be ineligible for federal tax credits.

\subsubsection{The Residential Conservation Service}

The Residential Conservation Service (RCS), operated by DOE, will require utilities to provide their customers with energy audits, making recommendations by household for saving energy. Some utilities will charge a nominal fee for this service while others will provide it free of charge. The RCS also enables utilities to develop financing packages for conservation and solar energy investments. Originally, the RCS defined its residential audience as buildings with 1 to 4 units only. Multifamily housing with 5 or more units in a building is now included in the audit portion of the program. Utility financing will be authorized only' for residential buildings with' 1 to 4 units, however.

While we have demonstrated that financing over time makes a conservation or solar energy equipment investment easier for a rental housing owner to make, utility financing alone has had little success with rental housing owners. This strategy, at the local level, is documented in more detail in Sec. 5.3.2.

\subsubsection{Federal Programs for Rental Housing}

The federal programs discussed thus far address the residential sector as a whole. However, the investment decision criteria differ markedly for homeowners and income property owners, especially in required rate of return, the impetus to consider conservation and/or solar, and in tax benefits. Federal programs that address rental housing in particular are mainly in the form of recent amendments to federal housing programs. HUD 
runs 14 housing programs that deal directly with multifamily housing. The legislation that pertains to energy efficiency in federally sponsored multifamily housing (20\% of all multifamily units) is found in amendments to three Acts: (1) the Energy Conservation and Production Act (ECPA); (2) the Housing and Community Development Amendments of 1978 to the National Housing Act of 1964; and (3) the National Energy Conservation Policy Act (NECPA). In general, the legislated changes require that recipients of HUD funding show that their properties meet the cost-effective energy conservation standards prescribed by HUD. It should be pointed out, however, that these programs affect only $8 \%$ of the entire rental sector.

\subsubsection{Energy Conservation and Production Act}

Amendments to ECPA allow HUD to offer conservation funding in four forms:

- grants of less than $\$ 400$ or $20 \%$ of the cost of conservation measures;

- low-interest loans (no limit șțated);

- interest subsidies on privately provided loans for conservation measures (no limit stated); and

- loan guarantees (no limit stated).

All four are available to both rental housing owners and tenants.

Until September 30, 1979, ECPA also allowed DOE to off er loan guarantees for energy conservation measures in multifamily housing of two or more dwelling units.

As noted, multifamily (five or more units) rental housing owners are of ten reluctant to take advantage of government grants or loan guarantees because of a general reluctance to increase government involvement in operating income property. Furthermore, it is not at all clear that the federally subsidized loans and grants have met with rental property owners' minimum economic investment criteria. Therefore, these programs are likely to be limited in their effectiveness, except where building owners are required to meet HUD's energy efficiency standards and cannot acquire funding elsewhere to do so.

\subsubsection{Housing and Community Development Amendments of 1978}

The Housing and Community Development Amendments of 1978 include three energyrelated changes in the National Housing Act of 1964.

Section 312 of the Act now authorizes HUD to make low-interest loans (3\%) to apartment building owners to rehabilitate low- and moderate-income housing. Apartment owners are eligible if the property has less than 100 units. The majority of the tenants must have low or moderate incomes, or the building must be in a neighborhood that is predominantly low- and moderate-income. The building owner must agree to limit rent increases for five years. Improvements made with loan money must meet HUD's costeffective energy conservation standards. Although this program has some potential, it has the major limitation of involving the Federal Government in building operations in the form of required standards and limited rent increases-regulations generally unattractive to owners of rental housing. 
Sections 236 and 221 of the National Housing Act provide assistance to help reduce operating costs of troubled multifamily housing projects. The energy-related change is that HUD's energy conservation standards must be met in the submitted plan to reduce operating costs.

Section 8 of the National Housing Act provides rent subsidies to tenants in nongovernment owned and operated housing. The amendment requires that owners of rental property subsidized by Section 8 funding must meet HUD's cost-effective energy efficiency standards. If the Section 8 subsidized properties are only marginally profitable, as apparently has been the case for most multifamily rental property (GAO 1979), then the added financial burden of making such changes may have the unintended effect of further reducing the stock of rental housing available to low- and moderate-income households, as owners abandon buildings or convert them to condominiums. There seems to be a strong case for providing financial assistance along with this mandatory amendment. However, for the combination to work, financial assistance should be provided in a form that least constrains the building owner's decisions.

Section 209 of the Amendments concerns solar energy. No funding has been made available for solar energy improvements on multifamily housing. This section merely encourages building owners to install passive and active solar energy systems.

\subsubsection{National Energy Conservation Policy Act}

Two sections of NECPA have been extended to give HUD further authority to insure loans and provide grants to multifamily housing owners for the purpose of conserving energy. However, as noted, multifamily rental building owners pref er incentives such as tax credits, accelerated depreciation, and long-term loans with or without subsidies rather than loan guarantees or.grants.

Section 247 of NECPA authorizes HUD to insure loans for energy-conserving improvements to multifamily housing projects. These include conservation measures, solar energy system installations, and changes from master-metered heating to separate meters.

Section 251 provides for HUD grants to finance energy-conserving improvements in federally assisted housing projects.

\subsubsection{Summary of Federal Rental Housing/Energy Programs}

In general, federal policies and programs designed to encourage conservation and solar energy use in rental housing are not sufficient. Not only do the incentives offered seem too few and too low, but the types of incentives offered are those leasl alluactive to many rental property owners. Although some programs provide for tax credits and financing packages, these address the residential sector as a whole. The specific problems of rental housing are not addressed; therefore, owners are less likely to take advantage of such programs.

The programs and policies addressed specifically to rental housing owners are most of ten either loan guarantees or grants that carry constraints. These constraints entail costs evidently perceived to outweigh the benefits that may accrue to rental housing owners should they invest in conservation measures or solar energy equipment for their properties. 


\subsection{STATE AND LOCAL PROGRAMS}

While federal programs directed toward rental property owners can be improved, when coupled with state and local incentives in a complementary or supplementary fashion, they can increase considerably the likelihood of investment. The Federal Government can encourage rental property owners to invest in conservation and solar energy by assisting local and state governments wherever possible.

State and local governments can respond more sensitively and flexibly to diverse barriers in local rental housing markets and can often achieve success when a federal program alone may not work. With building codes and, in some cases, rent control laws under their jurisdiction, state and local directives may be more capable of supplying the leverage needed to increase conservation and solar energy investment by rental housing owners.

For these reasons, and because the most innovative approaches to conservation and solar energy investment in rental housing seem to be originating from state and local governments, in the next section we describe a variety of approaches currently being developed at those levels.

\subsection{TYPES OP INCENTIVES}

Programs that encourage conservation and solar energy use in rental property are beginning to be designed and implemented at state and local levels. Although few such programs are in place at present, we will describe existing or planned programs here and analyze the likelihood of their effectiveness. The programs fall into five general categories that reflect major strategies now developing. Although programs do not always fit neatly into a given category, we have categorized them according to their major thrust and have indicated where specific programs use a combination of strategies.

The five strategy types are:

- programs for renters;

- economic incentives for landlords;

- leasing of solar equipment;

- mediation between landlords and tenants; and

- required solar energy use or conservation improvements.

We initiate each section with a discussion of the general strategy that analyzes both strengths and weaknesses of each type of incentive. At the end of each section is a list of programs that fall under the particular category. These lists will give policy makers an idea of the range of programs currently under way.

Lastly, though information and public education is not one of the categories listed above, we would like to stress the importance of this function. At the very least, disseminating conservation and solar energy information can help change wasteful behavior patterns of both rental housing owners and tenants. Information programs can include audit disclosures, fuel bill disclosure requirements, and energy ratings on rental housing units-as well as more conventional public education programs. In many cases, information dissemination alone may be sufficient to prompt conservation and solar investments in 
rental housing. Any local or state government attempting any of the programs discussed here should couple that program with an active information and education program that reaches all participants in the rental housing market-including owners, tenants, bankers, builders, and city officials.

\subsubsection{Programs for Renters}

The most common type of energy-related financial incentive off ered to renters comes in the form of an energy cost subsidy; the government pays for a portion of a tenant's use of conventional energy. Most such incentives for tenants are applicable only where tenants pay their utility bills directly, however. While these subsidies might be helpf ul and even crucial in assisting tenants in the short run, they provide very little assistance in the long run. In fact, these subsidies do not encourage conservation or solar investment and, therefore, are extremely limited.

Other forms of economic incentives for tenants, such as low-interest loans or tax credits, are also limited. The many legal and financial constraints inherent in tenants' status restrict their power to invest in conservation and solar energy. First; tenants usually have less disposable income available for conservation and solar investments than do landlords. But even with the requisite capital, tenants cannot make investments in their rented units unless they can get the owners' permission, and they can recoup their investments in energy savings. For all but the least expensive conservation devices, most conservation and solar investments have payback periods greater than the length of the average tenancy, which is less than three years. Therefore, economic incentives directed toward encouraging tenants to make conservation and solar investments will probably be successful only with devices that ensure short payback periods or with tenants who have long-term leases and owners' permissions to make any required changes in the property. Owners have some incentive to allow tenant investment because it could add to the value of their property, guarantee them a more energy-conscientious tenant, or keep tenants' energy costs at levels that do not affect their ability to pay rent. However, in spite of these incentives, the legal requirement of obtaining owners' permission can work as a disincentive for tenant investment.

An example of the restrictive nature of these financial and legal constraints is found in a recent Tennessee Valley Authority (TVA) program. For several years, TVA has been offering, to owners and tenants, an interest-free, seven-year conservation loan of up to $\$ 2,000$ per unit for any customer using electricity for either heating or cooling. Although TVA conducted many audits of rental property at tenants' requests, not a single tenant has requested a loan. Despite the favorable loan conditions, the greatest stumbling block, according to TVA, seems to be its own requirement that owners must approve any conservation installation beforehand and accept the financial risk of the loan in case a tenant should leave (either voluntarily or at the owner's request) before the loan is repaid. (David Lamb,|TVA).

While the legal and financial barriers to tenant investment in high-cost conservation and solar equipment seem extremely difficult to overcome, programs exist that can supply tenants with low-cost conservation devices. Many communities have designed charts of cost-effectiveness based on length of tenancy to urge tenant investment in conservation. These charts can be designed to reflect local climates, energy costs, conservation device type and cost, and rental housing conditions. Tenants in a given area and living in a glven housing typje can determine which investments are const-effective based on their planned length of occupancy. For instance, although it might be cost-effective for a 
tenant with a one-year lease in New England to install weatherstripping, in Florida two years might be required to pay back the same investment. Some of these less costly devices might require alterations in the rental property; however, the changes are generally insignificant, and obtaining owners' approval should be relatively easy.

Another way to encourage tenant investment in low-cost conservation devices is to identify those devices that tenants can take with them when they move, such as low-flow shower heads, energy-efficient light bulbs, and removable weatherstripping. This approach not only circumvents the need for owner approval (since no permanent change in the rental property occurs) but it also allows tenants to tolerate a longer payback period. However, while this particular approach might save an individual tenant some money, it does not make any long-term changes in the rental property itself.

Meanwhile, tenants encounter éven more difficulties investing in solar energy devices than in conservation, since most solar equipment is more expensive and because solar installations usually require significant or permanent modifications to rental property. However, there are a few moderately priced solar devices that tenants may use on rental property. A solar greenhouse or a bread-box water heater can be portable and thus easily attached to any rental property. Yet, obtaining owner approval for attaching these devices probably will be more difficult than for less visible conservation equipment.

While encouraging tenants to invest in conservation or solar energy measures can result in some important energy savings, we see that this approach is severely limited. It applies best in separately metered buildings, and the approach does not address conservation for common areas. Therefore, we conclude that programs designed solely to encourage tenants' investments are insufficient. Rather, programs designed to influence the investment behavior of rental property owners are more likely to have substantial longterm impacts in improving the energy efficiency of rental housing.

Portland, Oregon. Portland Sun, a local energy group, has designed a small ( $\left.8^{\prime} \times 10^{\prime}\right)$ greenhouse for renters which is readily detachable and portable; The system costs under $\$ 200$ and can be attached to a rental unit with only minor modifications to most property. Portland Sun has started a series of workshops to teach renters how to build these greenhouses. An additional advantage of a greenhouse is that it is attractive in mastermetered as well as separately metered buildings, because tenants can grow food while owners save money on their heating bills. Of course, investment barriers (e.g., obtaining owner approval) and problems involving solar access and space requirements-especially in high-rise housing-still remain.

Menlo Park, California. A project called PATCH (Practical Application for Teaching Conservation in the Household), funded by a California Energy Extension Service grant, has been set up in conjunction with the Briarpatch Cooperative Market in which $60 \%$ of the members are renters. The project's goal is to reduce energy consumption by $25 \%$ in members' rental units. The PATCH project has three basic elements:

- PATCH staff are available at Briarpatch for consultation. They also maintain a conservation library.

- A low-cost portable conservation device kit has been designed that renters can purchase as a whole or in parts, install in their rental units, and take with them when they move. The kit includes, among other things: low-flow shower heads, pipe insulation, a hot water tank insulating blanket, removable weatherstripping, lighting timers, and energy-saving gaskets for electrical outlets. Each device is 
accompanied by a chart illustrating the device's function and its expected payback period.

- Workshops are being conducted to assist renters in conserving energy. These workshops include:

- how to do your own energy audit;

- how to weatherize and insulate;

- how to install the devices sold in the portable kit; and

- how to build and install a portable solar bread-box water heater.

\subsubsection{Economic Incentives for Rental Property Owners}

As we stated in Sec. 4.0, there are several ways to make conservation and solar investments more economically attractive to rental housing owners. Two approaches, tax incentives and financing, attempt to minimize the adverse effects that conservation and solar investment could have on a rental property owner's annual cash flow and subsequent income tax liability.

Various types of tax incentives can be designed at state and local levels, perhaps with federal assistance, to encourage conservation and solar investment. One method is an accelerated depreciation allowance (rapid amortization) that allows investors to deduct from taxable income a large percentage of the value of their investments each year until they have deducted the entire investment over several years.

Complete or partial property tax exemptions for energy improvements made on rental property can also be an incentive for increased investment. As discussed in the context of the Energy Tax Act (Sec. 5.1.1), an energy tax credit that would allow rental property owners to deduct a fixed percentage of their conservation or solar investment from their federal and/or state income tax payments can be a significant incentive, depending on the size of the credit and the income tax liability. Furthermore, when an energy tax credit is coupled with a straight business investment tax credit deducted in the same way, the combined incentive could be substantial.

Adequate financing is also needed to encourage greater investment in conservation and solar energy. One problem rental property owners face with financing, especially for retrofit, is finding enough capital to make the investments. Banks, utilities, and government programs need to facilitate rental property owners' access to sufficient funds.

But while sufficient funds are crucial, improving the quality of the financial arrangements is equally important. A loan with a high debt-to-equity ratio with a slightly lower than market interest rate can be an attractive incentive to invest in solar and/or conservation for commercial property owners. Although some banks are beginning to offer long-term loans at relatively low interest rates, these programs are not widespread. It is not clear, either, that the terms of the loans are favorable enough to meet the investment criteria of many rental property owners. Meanwhile, a few utilities are beginning to help finance conservation and solar investments through interest-free or low-interest loan programs for both conservation and solar energy. When the utilities are willing to lend close to $100 \%$ of the investment, these low- or no-interest loan programs can eff ectively reduce or eliminate frontmend costs and keep monthly payments low for rental housing owners. If the monthly payments are lower than the displaced energy costs, rental property owners can show a positive or increased cash flow from the loan's onset. 
A combination of tax incentives and attractive financing terms will probably work better than either type of incentive alone. Yet, there is still a great need for experimenting with different combinations of economic incentives to determine the most effective mixes. For example, TVA's Memphis Solar Program installed a total of over 600 solar domestic water heaters in single-family dwellings after offering a 3.37\%, 20-year loan. However, this program did not attract a single rental property owner, even though owners were also eligible to claim the Federal Energy Investment Tax Credit (according to Bob Brown, TVA). At the same time, the Solar Center, a solar installation and consulting firm in San Francisco, has installed over 50 solar energy systems on rental apartment complexes. The Center informs rental property owners that they are eligible for the 55\% California tax credit and arranges a 20-year loan at slightly reduced interest rates with a local bank (according to Peter Barnes of the Center). While part of the relative success of the Solar Center is due to aggressive advertising and the formulation of an integrated package specifically tailored to owners of multif amily buildings, determining whether such a mix of economic incentives is effective or not calls for further testing.

Before designing economic incentive programs for rental housing owners, policy makers must distinguish between homeowners and rental-property owners since their investment criteria are different. Even within the rental sector itself, different sets of incentives must be provided where a clear distinction between rental property owner groups exists, whether they are distinguished according to building type or form of ownership.

An important question remains: How eff ective can even a well-designed economic incentive package be in encouraging conservation and solar-energy investment in rental property? Owners of master-metered rental housing, who pay utility bills directly, probably will be most responsive to economic incentives. To encourage conservation and solar energy investment by the remainder of rental property owners, who do not pay the energy bills directly, will be a more difficult task. However, incentives can be designed that make rental property more profitable with an investment in conservation and/or solar energy even for the latter group. Described below are several financial incentive programs that attempt to encourage rental housing owners to invest in conservation or solar energy equipment.

State of California. The present state solar tax credit affects rental properties in two ways. For systems costing less than $\$ 12,000$, a rental property owner can claim the $55 \%$ nonrefundable state tax credit after subtracting the federal tax credit. Therefore, if the rental property owner buys a $\$ 10,000$ solar water heating system, takes the $55 \%$ credit $(\$ 5,500)$ and subtracts the $15 \%$ Federal Energy Investment Tax credit $(\$ 1,500)$, the owner would be left with a $\$ 4,000$ state credit. However, since there is a $\$ 3,000$ maximum, the owner will only be able to deduct $\$ 3,000$ from her or his state income tax.

For systems over $\$ 12,000$, a rental property owner is allowed to deduct $25 \%$ of the system's cost from the state income tax. After subtracting the 15\% Federal Energy Investment Tax credit, an effective $10 \%$ California credit remains.

However, that tax credit expires at the end of 1980, and a new proposed credit is expected to clear the legislature shortly. Under the new credit, for systems greater than $\$ 12,000$, owners can divide the cost of their systems by the number of units in their structures and then take the full 55\% California credit-up to $\$ 3,000$ per unit. Furthermore, the proposed tax credit will permit the apartment building owner to take an accelerated depreciation allowance on the solar investment over a three-year period, in lieu of a tax credit. 
Other relevant amendments in the proposed California Tax Credit include:

- the incorporation of a refundable credit for people making under $\$ 15,000$ per year whose credits exceed their liability (this credit may not have much effect on rental owners because of their higher incomes);

- changing the swimming pool credit from $55 \%$ in 1980 to $45 \%$ in 1981 , and then decreasing it by $10 \%$ each year thereafter to $25 \%$; and

- allowing rental housing owners to take a $55 \%$ credit on the purchased portion and principle recovery portion of a solar energy system leased from a utility during the first three years of the leasing agreement.

The State of California has also enacted a $40 \%$ nonrefundable income tax credit to a maximum of $\$ 1,500$ for conservation investments. This tax credit went into effect January 1,1981 , and will be available to owners of rental residential property as well as hom eowners.

State of Rhode Island. Recognizing that the federal energy tax credit excludes rental housing owners who invest in conservation improvem ents, $R$ hode Island amended its taxation laws in 1980. Rhode Island allows owners of residential rental property to take a personal income tax credit of $20 \%$ of any expenses they pay to purchase and install energy-conserving items. The maximum allowable credit is $\$ 500$ per structure, to a total maximum of $\$ 5,000$. No more than $\$ 1,000$ may be taken in one year, although credits may be carried forward for five years.

Tennessee Valley Authority. To encourage energy conservation, TVA offers a free home energy audit to any residential customer. Customers using electric heating or cooling can obtain a seven-year, interest-free loan of up to $\$ 2,000$ per unit from TVA. The loan is available to both the tenants and owners of rental property, and although TVA has done many rental property audits, not one rental housing owner or tenant has requested a loan, although a few loans have been extended to a mortgage and management company. TVA is now engaged in energy conservation for public housing using HUD funds.

Though a TVA solar water heater loan is available to both owners and renters when the solar heater displaces an electric water heater, TVA believes that the Federal Energy Investment Tax Credit is not sufficient to spur investment (Bob Brown, TVA). Tenants are constrained by all the existing legal and financial barriers noted previously.

Eugene, Oregon. The City of Eugene has just formulated an interest-free, $100 \%$ financing conservation loan program for 1- to 4-unit residential structures under the federal RCS program. The no-interest loan will be offered to any unit using electric space heating. Owners of buildings that use other sources of heat are eligible for a lowinterest, 100\%-financed loan. The loans would be payable over a seven-year period (1/7 paid per year), with a one-year initial grace period. These loans will also be assumable. There is no provision to keep rental property owners from increasing rents in a way that would make rents plus utility bills higher after a conservation investment than before one. However, the city is considering implementing a conservation investment disclosure procedure.

The City of Eugene is also considering expanding the program beyond one to four units, to include all multifamily housing. If the conservation program is deemed successful, the city will consider adding solar domestic water heating to its conservation financing plan. While the present conservation strategy is voluntary, the city currently is consider- 
ing requiring compliance with a set of prescriptive conservation standards on resale, beginning in 1985. (See also Sec. 5.3.5.)

San Diego, California. Home Federal Savings and Loan in San Diego is offering a preferred-rate home-improvement loan to rental property owners for conservation and solar energy investments. The interest-rate reduction on any home improvement loan will increase proportionately with the percentage of the loan that goes toward conservation or solar investments. The savings and loan institution's theory is that increased conservation and solar investment will result in greater savings on utility bills and, therefore, more disposable income for the owner to pay the mortgage.

San Francisco, California. The Solar Center, a solar energy system installation and consulting firm in San Francisco, has already installed over 50 solar water heating systems on multifamily structures-affecting over 1000 units. The Center attributes its success to an aggressive marketing strategy and good financial packaging. At the core of its financial package is complete financing at a lower than market rate through a Safe Energy Fund established by the Center and offered by Continental Savings Bank. The Center also provides information about the applicability of federal and state income tax credits on any solar purchase. The Center has its own computer program, which enables staff to provide clients with the after-tax costs and benefits of a solar installation and operation.

Peter Barnes of the Solar Center believes that when the California State Tax Credit becomes $55 \%$ for systems over $\$ 12,000$ on multifamily housing, the Center's business will expand further. However, all of the Center's installations to date have been on mastermetered multifamily buildings, and Barnes thinks even the $55 \%$ credit will probably not expand its market to separately metered buildings.

Although some conservation and solar energy equipment investment can surely be encouraged by increasing levels of loan subsidies and tax credits, achieving economic incentive levels that will significantly affect investment may be too expensive for local or state governments. It is unlikely that the majority of rental property owners will invest in conservation and solar energy as a result of economic incentives alone. However, combining economic incentives with other approaches, such as leasing or regulatory actions, can aff ect a greater percentage of rental housing stock.

\subsubsection{Leasing Solar Energy Systems}

Given the current state of the U.S. economy, in which investment capital is difficult to obtain, leasing is becoming a popular way of acquiring commodities. In the case of solar energy devices, the role of leasing company can be assumed by a utility, a local government department, or a private business. Lease payments can be made monthly or as a fixed percentage of the resultant energy savings.

A leasing program seems to address adequately many of the concerns of rental housing owners about a solar investment. By leasing a system instead of purchasing one, owners can reduce their initial capital outlay considerably. Usually, the only initial investment is for installation (approximately $20 \%$ of a system's cost), but occasionally even the installation fee is assumed by the lessor. Eliminating the front-end costs can be a big incentive for an owner.

A leasing program also has the advantage of considerably reducing the owner's financial risk. A rental housing owner does not have to tie up capital in a leased system. More 
importantly, an owner's liability is reduced should the system fail or the leasing company go out of business. Furthermore, when the leasing company is the local utility or city government, or even a local, well-established firm, the credibility of the program may be enhanced. Finally, a leasing program may be attractive to rental housing owners because the maintenance costs are assumed by the leasing company. Since high maintenance costs can reduce profits, this arrangement may be a positive incentive for building owners.

Rental housing owners may receive several tax benefits from leasing a solar energy system. While, in some areas, an owner's property tax assessment may increase if a solar energy system is purchased outright, leased systems are exempt from property tax. In some cases, the owner leasing the system may be allowed an investment tax credit that adds an extra incentive for building owners to lease solar energy systems. Offering a tax credit to the leasing company as well may spur leasing activity considerably. Finally, a leased system may be less risky because a lease can be terminated more easily than a purchased system can be sold, thus eliminating concerns over possible loss of solar access.

In separately metered multifamily and single-family rentals for which the owner does not pay the energy bills, there is little incentive for owners to lease a solar energy system. While leasing directly to tenants is possible, many potential barriers exist. One of the biggest problems is the leasing company's desire to deal directly with the owners, who are considered more stable and reliable. Even if companies were to lease directly to tenants, the tenants would need the owner's approval before installing the system. It is likely that the leasing company would require the owner's financial guarantee as well. Leasing companies may also require a certain minimum leasing period which a tenant may not be able to commit to, and an owner may not be willing to assume responsibility. Lastly, if a program is designed that requires a large initial installation charge, leasing may not be economically feasible for most tenants, especially for those with low incomes or with short-term tenancies.

Leasing has some limitations and promises more success in certain parts of the rental sector than in others. In general, leasing is probably most applicable to multifamily rentals that still have master-metered utilities. In this situation, owners still pay the utility bills and thus have the greatest incentive to conserve energy. But even in mastermetered units, that incentive is diminished in rent-controlled areas that require owners to pass on energy savings in the form of decreased rents.

City of Santa Clara, California. Santa Clara has been operating a solar utility through its Water Department since 1978 and has installed over 160 leased systems. The city installs and maintains the solar heating system and the customer pays for the initial installation and a monthly service charge. Twenty of the 160 systems are used for multifamily rental swimming pool heating where the leasing fee is charged only during the sixmonth pool heating season. Solar domestic water heating service has recently begun, and the city expects to have some penetration into the multifamily rental market in the near future.

Phoenix, Arizona. A private company, J \& J Solar, leases a patented aluminum solar collector/roof shingle system for space, swimming pool, and domestic water heating, or any combination thereof. $J \& J$ installs the system free and claims the Arizona and federal commercial investment tax credit. Monthly payments are equal to $80 \%$ of the money saved on energy bills as determined from the previous year's bill. Meanwhile, the building owner makes no initial investment, assumes no financial risk or maintenance costs, 
and saves $20 k$ of every energy dollar displaced. After eight years the owner can buy the system, renew the lease, or have the system removed. As of July 1980, J \& $\mathrm{J}$ has leased seven large systems for multifamily complexes.

It is important to note that it would not be economical for $\mathrm{J} \& \mathrm{~J}$ to lease systems in this manner without the investment tax credit. Furthermore, the company was quick to point out that it is not yet economical to lease systems for single-family dwellings.

Palo Alto, California. Recognizing the limitations of financial incentives for motivating rental housing owners to invest in solar energy, the city has proposed a Municipal Solar Utility as an addition to its well-established municipal utility; specifically for leasing solar energy systems for rental housing. The solar utility would conduct a solar feasibility audit of the rental property, then install and maintain a solar domestic hot wuler system (where applicable). Lease payments would not exceed the cost of utility bills before installation and would be paid with utility bills.

At first, the program would be voluntary. However, if solar conversion in rental property does not progress at a satisf actory rate, the city would consider requiring building owners to choose between leasing a solar energy system from the city or purchasing their own systems from a private company. This program is still in the proposal stage.

\subsubsection{Mcdiation}

A mediation approach to increasing conservation and solar energy use in the rental sector requires cooperation between owners and tenants. This approach is intriguing because it recognizes that any long-term solution to the energy problem in rental housing will require participation-even compromise-on the part of both groups.

One advantage of mediation is that it is based locally. Reflecting local conditions such as types of housing stock or whether there are rent control regulations, mediation can tull or an energy program to conform to local needs. In a sector as diverse as we have outlined, the use of a locally responsive mechanism is important.

The mediation process can be used to work out different types of energy agreements between owners and tenants. These agreements can range from the way utilities are paid in an individual unit, to the rate at which an owner pays off a conservation investment, to a cost-sharing solar leasing scheme.

Where rent control is currently in effect, the rent control board is already a local mediator. Although the board's role regarding energy is usually to regulate rent increases resulting from rising energy costs, that role could be expanded to encourage equitable conservation and solar cost-sharing investments. It is also possible for rent control boards to restrict an owner's ability to pass on rising energy costs until certain conservation investments are made. However, this strategy alone may have adverse impacts on the local rental market. Where rent control does not exist, mediators can be utilities, the local government, or even a professional mediation firm.

Though mediation offers some exciting possibilities at local levels, it does have some inherent drawbacks. Since mediation works best on a case-by-case basis, it tends to be a long and arduous process, too slow and cumbersome to meet the urgency of rental housing's energy problems. Unless the mediation is binding, it may be fairly ineffectual. Moreover, mediation may not mitigate the legal and financial advantages that owners 
have over tenants. Mediation by itself may not provide sufficient economic incentives to spur rental property owners toward investment.

Santa Monica, California. The Santa Monica Energy Project, funded by a California Energy Commission Fnergy Extension Service grant, is encouraging conservation measures and solar energy use in its rental sector (which accounts for $80 \%$ of Santa Monica's housing stock). The approach is to work with both owners and tenants wherever possible. Besides conducting workshops on general energy-conserving techniques, the Project is providing additional workshops for tenants in energy-auditing their rental units, for owners and landlord associations in the economic benefits of conservation and solar investment, and for bankers in the importance of providing funding. The Project is working with each rental market interest group and the Santa Monica Rent Control Commission to promote the installation of energy-efficient equipment, especially devices with $50 \%$ or better return on investment, while developing an equitable way to pay for conservation and solar energy systems over time.

Wisconsin Power and Light (WPL). This utility has begun an ambitious program to weatherize the 25-30,000 rental units in its service area. The program involves audits of rental properties for owners, audits for renters dealing with energy conservation behavior measures, seminars geared to a variety of subjects and interest groups, demonstration retrofits, and communitywide educational programs.

At the center of this effort will be the creation of a rental property conservation advisory committee in each community under the utility's jurisdiction. The committee will include representatives from rental housing owners, tenants, financial institutions, realtors, local government, and WPL. The committee will "develop a realistic program to achieve the division goals for weatherization of rental properties in their area through a cooperative effort ... and develop a strong base of support within the community for the program" (Wisconsin Power \& Light Program Description).

The fact that WPL is not offering any financial incentives might be a drawback if owners cannot acquire financing elsewhere. However, WPL will give an energy-conserving certificate seal to any rental property that meets state standards, which are still being developed. WPL thinks that the slight competitive advantage that such a seal can provide will create some incentive for owner investment. However, because of nationwide tight rental housing markets, this type of program's influence probably will be limited.

As of June 1980, WPL had conducted 1400 energy efficiency checks at rental owners' requests. Where recommendations were made af ter an audit, 50 units have been completely weatherized, 50 are partially weatherized, and another 100 are in the process of being weatherized. It appears that even though this program is in its infancy, it is already having some success. Unfort unately, the entire program has been tabled temporarily because of a disagreement between the State Public Service Commission and the state legislature regarding mandatory conservation standards (see discussion in Sec. 5.3.5).

Cambridge, Massachusetts. Another potential area for mediation lies in determining a fair. rate of amortization of conservation in rent-controlled areas. The City of Cambridge rent control board has passed a conservation escalator clause that allows owners to pass on the entire cost of conservation investments to tenants as part of the rent. Though this type of program is a step in the right direction, there are two points that need careful attention. First, it is important that owners do not amortize their entire investment cost over a relatively short period of time, or tenants will pay more 
for utilities plus rent than if there had been no investment. Second, in some situations it might be more equitable for owners and tenants to split the investment cost between them rather than pass on the entire capital cost to tenants.

\subsubsection{Regulatory Actions Geared to Rental Housing Owners}

Requiring that rental housing attain certain levels of energy efficiency is an alternative approach to promoting conservation and solar energy in the rental sector. This particular approach is rapidly gaining popularity at state and local levels as a way of surmounting the difficult economic and institutional barriers encountered in making rental housing energy efficient.

The most typical forms of regulation are changes in building codes, which require increased use of conservation and passive solar heating in new construction. Several local governments have also required the installation of solar water heating equipment for all new housing. Several state and local governments have implemented conservation ordinances that require compliance either by a certain date or at the time of resale. One county even requires that solar water heating be incorporated in each residential building upon resale. While most of these statutes have been directed at the entire residential sector, a few have been limited to rental housing.

Other regulatory actions being passed that affect energy conservation and solar energy use in rental housing include:

- banning master metering (discussed in Sec. 3.3.1);

- coupling regulatory actions with leasing (discussed in Sec. 5.3.3);

- combining economic incentives with regulatory action (discussed in Sec. 5.3.2); and

- allowing a portion of conservation and solar investment costs to be passed on to tenants in rent-controlled areas (discussed in Sec. 5.3.4).

There are several advantages to an approach that requires energy conservation and the use of solar energy. Perhaps the most important benefit is that a regulatory approach increases the speed of market penetration. Though a well-designed financial incentive or leasing program alone can undoubtedly encourage some rental property owners to invest in conservation or solar energy, because of all the institutional, legal, and financial barriers already noted, there will still be large pockets of energy-inefficient rental property. A regulatory approach assures a more unif orm and deeper market penetration.

Governments usually use regulatory actions to fill a gap created when a perceived social or economic need is not being met by the market. For example, before San Diego County passed the nation's first solar water heating ordinance for new residential construction, the county did a market penetration analysis that clearly showed the advantages of a regulatory approach over the California state tax credit alone. The projected discrepancy between the two figures was largely attributable to the perception of costeffectiveness by both builders and homeowners. While the county had determined that, on a life-cycle costing basis, solar water heating was cost-effective for every building properly accessed, they felt that without an ordinance many people would use alternative criteria for determining cost-effectiveness, or make no calculation at all, and then not invest in a solar water heater. 
Clearly, owners of rental property are a group whose criteria for cost-effectiveness are often different from those of homeowners, and usually their rate-of-return calculations are not as favorable toward conservation or solar investments. Since, in the majority of the rental housing units, utilities are paid by tenants and not owners, there is little hope that owners will determine cost-effectiveness based on energy displacement costs. But even where owners still pay utility bills, their investment criteria are usually more complex than simple life-cycle costing; it is not clear that this group will purchase conservation or solar devices on its own initiative.

While the regulatory approach might be most successful in achieving the greatest number of energy-efficient and solarized rental units in the shortest possible time, it will also meet with the greatest political resistance. Local and state governments can minimize this resistance by emphasizing that conservation and solar ordinances are changes in existing codes and ordinances rather than unprecedented mandatory encroachments on the private sector. While higher costs and lack of familiarity with some conservation and solar energy devices seem to make energy regulations unique, they are actually analogous to many preceding building code provisions and amendments.

Any regulatory approach applied to rental housing, however, must take into account the unique set of circumstances found in the rental sector. For instance, if solar domestic water heating is required on rental housing but provisions are not made for owners to pass on costs to tenants, there may be adverse effects on the rental housing market. In cases where such investments would substantially increase the owner's operating costs, owners may choose to convert to condominiums, or, in cases of marginally profitable (generally low-income) units, the owner may abandon the property altogether. Both owner responses would result in fewer rental housing units in a market that is already shrinking.

While policy makers must become familiar with any potential hardship that a regulatory approach might have on rental property owners, they must also become familiar with problems precipitated by an inequitable distribution, under a regulatory scheme, of the owner's investment costs to the tenants. When owners can pass on their investment costs to tenants in the form of increased rents, it is important that the rent increases in separately metered buildings do not offset the subsequent energy savings on tenants' utility bills. In a master-metered building, it is important that if owners raise rents to cover the energy equipment investment that they also pass on any of the energy savings, either through lower rents or stabilized rents.

Policy makers must be especially sensitive to this dilemma in non-rent-controlled areas where it is easier for owners to raise rents. However, even where rent control is in effect, it is critical that conservation or solar investment costs be paid via rent increases in a way that does not completely offset energy savings. Making the owner's conservation and solar investment costs and financing information available to tenants may be a first step in developing an equitable transf er mechanism of owner investment costs to tenants. However, this strategy may meet with protests from owners.

Presented here are six examples of regulatory conservation programs and three examples of local governments that require solar energy use. It should be noted that all existing regulatory strategies are accompanied by federal and/or state tax credits, and in some cases by state, local, or utility financing.

Minnesnt.a. This state passed an ordinance in 1978 that required owners of rental property built before 1976 and occupied each year between November and April to comply 
with a set of conservation standards by 1980 and a second, more stringent set by 1983 . The 1980 list of required devices all had payback periods of less than 10 years.

Although the January 1980 deadline has passed, it is not clear what levels of compliance have been achieved. The enforcement mechanism in this case is extremely weak, and substantial revenue is required for this type of ordinance to be policed properly. Since Minnesota does not have rent control, there is no mechanism for ensuring that owners either pass on or absorb the costs of their investment in an equitable fashion. The provision in the original bill to prevent owners from recouping their investments in less than five years was deleted because rental housing owners protested.

Davis, California. As of January 1, 1980, all housing in Davis is required to comply with certain conservation standards at the time of resale. After conducting an audit, the city will inform the seller what items are needed for compliance. Such required items include R-19 insulation in ceilings, water heater insulating blankets, low-flow shower heads, and adequate weatherstripping. There is a $\$ 500$-per-unit upper limit on the amount of money a resident or absentee owner is expected to spend.

Santa Clara County, California. A county ordinance passed this year requires certain conservation standards to be met at the time of residential resale. An audit will be performed by the county, and compliance will be certified by either the buyer or seller of the property. Compliance for attic insulation must be validated by an auditor or licensed contractor.

Portland, Oregon. Portland initiated a voluntary conservation program on August 15, 1979, for its residential sector. Af ter five years, weatherization will be required at the time of resale on both owner-occupied and rental housing. Conservation standards in rental property may also be enforced at the time of a single unit's turnover. This provision might cause some inefficiencies. First, it might be more costly for rental property owners to install conservation devices in each individual unit at different times than to weatherize the whole building at once. Second, compliance at the time a unit is turned over does not affect common space until the entire building is sold. The list of Portland's requirements includes all renewable devices which meet a 10-year simple payback analysis.

Eugene, Oregon. Eugene has developed a no-interest loan program (presently awaiting federal approval under RCS) to encourage conservation in 1- to 4 ; -unit dwellings (see Sec. 5.3.2). Eugene also intends to pass an ordinance that will require compliance by 1985 to a list of energy efficiency standards. The ordinance will apply to all 1 t to 4)-unit structures buil before 1974, and will require $R-30$ ceiling insulation, attic ventilation, insulation between floor and unheated space, R-11 insulation on water heaters, caulking and weatherstripping to ASHRAE standards. Compliance. will be required on a utility change of service. This arrangement puts the burden on the buyer, which the city sees as guaranteeing a more careful installation than if the seller does a rush job. Also, this method will require compliance when a rental unit turns over, which may raise the same problems as Portland's plan.

Wisconsin Power and Light Co. The mediation approach for conservation in rental housing (see Sec. 5.3.4) has been temporarily thwarted by a confusing dialogue between the Wisconsin State Public Service Commission (PSC) and the State Legislature over requiring conservation standards. The PSC wants to promulgate standards by 1983 which would have to be met by 1985 . Buildings would have to comply within 6 months after the unit is audited. However, while the PSC's standards would apply only to rental units using natu- 
ral gas, the state's standards would apply to all rentals. Furthermore, the state would like to require compliance on resale after 1985, and continuation of a voluntary program until that date. In all likelihood, the PSC will defer to the state's plan; however, WPL's voluntary approach will not be started again until the confusion is settled.

San Diego County, California. In 1978, San Diego County was the first area in the country to require solar domestic water heating on all new construction in unincorporated areas. Initially, the ordinance was designed to affect only areas that could not be served by natural gas, with natural gas-served areas phased into the program by October 1980 . Arranging the ordinance in this fashion allowed time for the solar industry to gear up and for rising gas prices to make solar water heating in gas-served areas more economical.

Santa Clara County, California. The county passed an ordinance requiring solar water heating on all new residential construction in unincorporated areas. The ordinance became effective February 1980, and only buildings not receiving sufficient solar access are exempted.

In addition to requiring solar water heaters for new construction, the county was the first in the country to require solar water heating on all existing residential structures at the time of resale. Exemptions will be granted for inadequate solar access or excessive installation costs. Installation of the solar energy system can be secured by either the seller or the buyer, but in either case it must be installed within 100 days of the close of the sale. This part of the ordinance takes effect in January 1983.

Kauai County, Hawaii. The county requires all new multifamily construction having 10 units or more-including hotels and motels-to install solar domestic water heating equipment. Units can be exempted only if they show that a conventional system would be more cost-effective with a 10-year life-cycle costing analysis.

\subsubsection{Summary of Incentive Programs}

The types of programs currently being developed on state and local levels to encourage conservation and solar investment in rental property consist of five major strategies. Any program to encourage energy efficiency in rental housing must combine these strategies in a way that will best address local rental housing market conditions. No single strategy is likely to be effective on its own. Summaries of the benefits and limitations of these strategies follow.

\section{3,6,1 Programs for Tenants}

While providing programs for tenants has the advantage of addressing actual energy consumers in rental housing, the potential is limited to low-cost items with short payback periods or portable conservation devices which tenants can take with them. In the case of no-cost or low-cost conservation efforts, tenant programs can be most effective in promoting these measures as a first step in increasing the energy efficiency of rental units. However, both legal and financial constraints on the tenants' ability to invest restrict any potential investment in more expensive conservation measures or solar installations. 


\subsubsection{Economic Incentives to Rental Property Owners}

The biggest advantage of economic incentives that combine tax benefits and attractive financing is that packages can be tailored to address owners' varied decision-making criteria within the rental sector. By decreasing the liabilities associated with conservation or solar energy investment, these incentives can effectively encourage rental property investment. However, the foregone tax revenues associated with adequate economic incentives can be too costly for local or state governments. Economic incentives will be most effective in master-metered buildings where owners still pay utility bills directly. It will be more difficult (and costly) to design economic incentives for separately metered rental housing.

\subsubsection{Leasing Solar Energy Systems}

Leasing a solar heating system might be more attractive to rental property owners than purchasing one, because of lower initial investments; smaller financial risks; and the low, predictable maintenance costs associated with leasing. However, even leasing will be most attractive to the owners of master-metered buildings where the owner pays the utility bills. While leasing might be applicable in separately metered buildings where the tenants could pay leasing fees directly, the tenant usually is restricted from entering into a leasing agreement without the owner's permission. The owner has little if any economic incentive to agree to such an arrangement, especially in cases where the leasing agent requires the owner to be responsible for the tenant's agreement.

\subsubsection{Mediation}

Two advantages of a mediation approach are that its purpose is to get owners and tenants to work together, and it can be responsive to local conditions. However, the mediation process is of ten slow and might be met with resistance from rental property owners. Furthermore, mediation might be difficult to administer and enforce without some sort of regulatory element included in the process. Mediation solutions alone may not provide enough of an economic incentive for rental property owners.

\subsubsection{Regulation}

This approach has the potential to produce the fastest and deepest market penetration of conservation and solar energy use in rental housing. Also, a regulatory approach can be designed to produce a more equitably distributed impact on users and owners than any other approach. However, regulation is of ten politically unpopular. Depending on the design and compliance levels, enforcing a regulatory approach could be expensive. 'When regulation is not carefully coupled with adequate economic incentives and other protections (e.g., solar access), rental property owners' profits might decrease enough to increase condominium conversion and abandonment. Finally, tenant protection must be provided to avoid a situation where owners pay off their required investments through increased rents in a way that offsets all the resultant energy cost savings to tenants.

Again, while all of these different program types have their associated costs and benefits, most of the programs outlined here can be most effective in combination. For example, providing sufficient tax credits and financing packages in conjunction with requiring solar domestic water heating at the time of resale can alleviate the high initial 
investment costs that might otherwise be incurred and thus make the regulatory action more palatable. Likewise, improving tax credits for leasing solar energy systems, both in terms of the level of the credit and its availability, would probably make leasing more attractive to rental property owners. 
THIS PAGE

\section{WAS INTENTIONALLY \\ LEFT BLANK}




\section{SECTION 6.0}

\section{CONCLUSIONS}

\subsection{MAJOR FINDINGS}

This preliminary report points out that the tremendous variety in local rental housing markets makes it impossible to recommend a single policy or program as a nationwide solution to rental housing and energy problems. Further research may provide an opportunity to better detail recommendations for policy or program action at the federal, state, and local levels. At this stage of analysis, we off er three general conclusions:

- In energy policy or program design, it is essential to disaggregate the residential sector to differentiate between owner-occupied housing and rental housing because investment criteria and incentives to invest differ for the two types of property owners. In addition, it is important to disaggregate the rental housing sector itself. Local rental markets vary, and so do the solutions to their energy problems.

- For no-cost or low-cost energy improvements, programs for tenants can have an impact on energy savings. For more extensive energy conservation or solar energy improvements to rental property, energy policies or programs designed to influence the investment behavior of the rental housing owner will have the greatest impact. Programs for tenants are important; however, they do little or nothing to make permanent energy efficiency-enhancing changes to the property.

- The tremendous variation in local housing markets means that energy policies or programs must be designed to address specific problems in the local market. We have outlined five program study strategies: (1) programs for renters, (2) financial incentives for rental housing owners, (3) leasing solar energy systems, (4) mediation, and (5) regulation. Each strategy has its advantages and disadvantages, although some disadvantages may be alleviated by combining strategies.

\subsection{RECOMMENDATIONS}

Government policy makers should not consider the residential sector a homogeneous group as they formulate policies intended to spur conservation and solar energy investment. Failing to disaggregate the residential sector according to housing and ownership types, and continuing current policy trends that are generally more effective for owneroccupied dwellings than for rental property, will result in far less energy savings in the residential sector than could be achieved. Since rental housing constitutes over $35 \%$ of housing in the United States, concentrated in urban areas and occupied predominantly by low-income penple, the potentially negative impacts of failing to address the rental sector's problems are tremendous.

Policies that address rental property owners more directly must also recognize the diversity that exists in the rental housing market itself. As we have shown, rental housing stock in the country varies by region, by structure type, by fuel type and fuel use patterns, by type of ownership, and by the presence or absence of rent control. When all these factors are combined in their various permutations, they present different sets of problems. Policy makers should take this diversity into account so they can tailor programs more precisely to each particular set of needs, as well as determine the likely impacts and eff ectiveness of proposed programs. 
The Federal Government has already implemented several programs to encourage greater conservation and solar energy investment in the residential sector. While a few of these programs may affect the decision-making process of the rental property owner, most of them do not directly address the rental owners' investment criteria, but rather, lump homeowners and rental property owners together. Rental housing owners' decisionmaking criteria involve short payback periods and great uncertainty about the profitability of energy-related investments. Because these federal programs do not take these concerns into account, the programs have been fairly ineffective in the rental sector.

Even HUD programs, more specifically tailored to rental property owners, have not been effective in encouraging much conservation and solar investment. One reason is that the programs have all used either guaranteed loans or grants which, according to a Booz, Allen \& Hamilton report (1979a), are the least desirable forms of incentives, at least to the multifamily rental property owner. Even if these incentives were effective, they are offered only to subsidized multifamily rentals, which account for a mere $8 \%$ of the entire rental market.

In addition to federal residential conservation and solar energy programs, much activity occurs at state and local levels in the United States. Some of the programs implemented at these levels have actually attempted to distinguish homeowners from rental property owners and address rental housing problems specifically. The greatest advantage state and local programs have is their ability to be more responsive to particular local conditions. Through existing powers such as building codes and, in many cases, rent control boards, state and local level initiatives have certain inherent mechanisms that can provide effective leverage in the rental market where federal incentives may not be as effective.

We do not make any specific program recommendations here: The rental housing sector is a diverse market whose energy problems require a variety of solutions. Furthermore, many of the state and local programs described here are in their infancy; therefore, their overall success or failure is difficult to assess. While no one solution will be best for every state or locale, this analysis may be useful in assisting policy makers at every level of government to develop programs that are appropriate to their particular jurisdictions. 


\section{SECTION 7.0}

\section{BIBLIOGRAPHY}

Andreassi, Michael; et al. 1980. The Impact of Residential Energy Consumption Standards on Households. 1344-05. Prepared by The Urban Institute for HUD's Office of Policy Development: and: Research.

Ashworth, John; et al. 1980 (Apr.). Building Markets for Solar Energy and Energy Conservation. (Working paper.)

Bleviss, Deborah. 1980 (Jan.). Rental Housing. Prepared for Federation of American Scientists. (Draft). Washington, DC.

Blew, Joseph Miller; Stevenson, Howard H. 1977. "How. to Understand a SubsidizedHousing Syndication." Real Estate Review. pp. 42-51.

Blew, Joseph Miller. 1979. Note on Government-Assisted Multi-Family Housing. Cambridge, MA: Harvard College.

Booz, Allen \& Hamilton. 1979a (May). Achieving Energy Conservation in Existing Buildings. Prepared for DOE. Bethesda, Md.

Booz, Allen \& Hamilton. 1979b (June). Alternative Metering Practices: Implications for Conservation in Multifamily Residences. Prepared for DOE; HCP/M 1693-03. Bethesda, MD.

Bureau of the Census: Housing Division. 1979 (Oct.). Annual Housing Survey-1977 National Sample-DOE Supplemental Tabulations. Washington, DC.

California Energy Commission, Energy Extension Service. 1980. PATCH program for tenants, program description. Menlo Park, CA: Briarpatch Cooperative.

California Energy Commission. 1980 (June). California Plan for the Residential Conservation Service. P400-80-062. Sacramento, CA.

California Energy Commission, Solar Office. 1980 (Apr.). Decade of the Sun. P500-80-022. Sacramento, CA.

Center for Renewable Resources. 1980. Shining Examples: Model Projects Using Renewable Resources. Washington, DC.

Corsin, Don; Sadler, Sam. 1980 (Feb./Mar.). "Keeping Tenants Toasty: Rental Weatherization." Rain. pp. 16-18.

Dietz, Thomas, 1979 (Dec.). Social Impacts and Solar Policy Options. Prepared under California Energy Commission Contract \#500-79-029. Davis, CA.

Dolbeare, Cushing. 1979 (Oct.). "Weatherization Programs for Low-Income People." Statement before the Senate Committee on Labor and Human Resources. Washington, $D C$. 
Fallon, Michael P. 1979 (May/June). "New Generation of Energy Management Systems Can Ease Energy Crunch." J. of Property Management. Vol. 44 (No. 3).

Ferrey, Steven. 1978 (Dec.). "How Carter's Solar Program Could Eclipse the Cities." Planning Magazine. pp. 20-23.

General Accounting Office. 1979 (Nov.). Rental Housing: A National Problem That Needs Immediate Attention. Prepared for the U.S. Congress. CED-80-11. Washington, DC.

Harvard Business School. 1972. Note on Forms of Real Estate Ownership. Cambridge, MA: Harvard College.

Harvard Business School. 1973. Financial Analysis of Real Property Investments. Cambridge, MA: Harvard College.

Harvard Graduate School of Design. 1976. Sources of Real Estate Information. Cambridge, MA: Harvard University.

Institute of Real Estate Management. 1979. Income Expense Analysis: Apartments. Chicago, IL.

J \& J Solar, Inc. 1979. Various brochures and product descriptions. Phoenix, AZ.

Klepper, Martin. 1979 (Spring). "The National Energy Act: Its Impact on Real Estate and Real Estate Financing." Real Estate Review. Vol. 9 (No. 1): pp. 40-49.

Lett, Monica. 1976. Rent Control. New Brunswick, NJ: Rutgers University.

McKenzie, Dennis J.; Betts, Richard M. 1976. The Essentials of Real Estate Economics. New York, NY: John Wiley and Sons, Inç,

McMahan, John. 1976. Property Development: Effective Decision Making in Uncertain Times. New York, NY: McGraw-Hill Book Co.

National Center for Appropriate Technology. 1979 (Dec.). Energy and the Poor: An Imperative for Action. Washington, DC.

Sanger, John M. Associates. 1980. "Municipal Solar Utilities: Draft Generic Issues Report Prepared for California Solar Utility Development Authority." Unpublished paper.

Santa Monica Energy Project. 1980. Project Overview. Unpublished memorandum.

Santa Monica Energy Project. 1980. Three-Month Work Plan. Unpublished memorandum.

The Solar Center. 1980. Various brochures and program descriptions. San Francisco, CA.

Sternlieb, George; Hughes, James W. 1980 (Jan./Feb.). "Rent Control's Impact on the Comm unity Tax Base." J. of Property Management. 
Stevenson, Howard H.; Poorvu, William J. 1976. Note on Taxation. Cambridge, MA: Harvard College.

Sumichrast, Michael. 1979 (Dec.). Housing for the 1980's. Prepared for National Association of Home Builders.

Sussman, Gennif er. 1980 (Nov.). Unpublished memorandum.

U.S. Department of Commerce: Bureau of Census, and Department of Housing and Urban Development: Office of Policy Development and Research. 1979 (June). Annual Housing Survey 1977. Volumes A-F. Series H-150-77.

U.S. Department of Commerce, Bureau of Census. 1977. Annual Housing Survey. 1976 Tape. Washington, DC.

U.S. Department of Energy. 1979 (Oct.). Characteristics of the Housing Stock and Households: Preliminary Findings from the National Interim Energy Consumption Survey. DOE/EIA-0199/P. Dist. Cat. UC-13.

U.S. Department of Energy: Office of Consumer Affairs. 1979 (Oct.). Impact of Rising Energy Prices on Low-Income Consumers: Test of Am erican Standards of Social and Economic Justice. Washington, DC.

U.S. Department of Energy. 1980 (Feb.). Residential Energy Consumption Survey: Conservation. DOE/EIA-0207/3.

U.S. Department of Housing and Urban Development: Office of Policy Development and Research. 1980. The Conversion of Rental Housing to Condominiums and Cooperatives. Washington, $\overline{\mathrm{DC}}$.

Valachi, Donald J. 1979 (July/Aug.). "The Arithmetic of Real Estate Tax Šnelter." J. of Property Management. Vol. 44 (No. 4).

Wall Street Journal. 1980 (3 July). "Conversions to Condominiums and Co-ops Aren't a Significant Problem, HUD Finds." p. 12.

Wheeler, Ellen. 1980 (9 June). "Apartment Renters May Pay Share of Heat Casts." Denver, CO: Rocky Mountain News.

Whiteaker Energy, Inc. 1980 (Feb.). Rental Weatherization Proposal. Prepared for Neighborhond Fonnomic Development, Inc., with a grant from the National Center for Appropriate Technology. Eugene, OR.

Wilson, Richard. 1979 (May/June). "Financial Methods for Making Energy Management Decisions." J. of Property Management. Vol. 44 (No. 3).

Wisconsin Power and Light. 1979. Conservation Program: Rental Property Advisory Committee. Unpublished paper.

Wisconsin Power and Light. 1980 (June). Conservation Program: - Testimony of Lyle Murton on Conservation Proposals for Rental Living Units. 


\section{THIS PAGE \\ WAS INTENTIONALLY \\ LEFT BLANK}




\section{APPENDIX A \\ INTERVIEWS}

Interviews conducted during June and July 1980:

Peter Barnes

Solar Center, San Francisco, CA

Heather Ball

Santa Monica Energy Project, Santa Monica, CA

Teresa Bertsch

PATCH, Menlo Park, CA

Deborah Bleviss

Federation of American Scientists, Washington, DC

Ken Bossong

Citizens' Energy Project, Washington, DC

Bob Brown

TVA Solar Program, Memphis, TN

Gary De Loss

Massachussets Energy Office

Steven Ferrey

National Consumer Law Center, Boston, MA

Joel Friedman

U.S. Department of Housing and Urban Development, Washington, DC

Aimee Gemeiner

New York City Housing Preservation and Development Department, NY

Jan Hamrin

Solar Office, California Energy Commission, Sacramento, CA

Steven Heim

County Planning Department, Santa Clara County, CA

David Lamb

Supervisor, TVA Home Insulation Program, TN

Nancy Lindborg

PATCH, Menlo Park, CA

Peter McLaughlin

Urban Caalition of Minneapolis, MN

David Morr is

Institute for Local Self-Reliance, Washington, DC

Lyle Murton

Wisconsin Power and Light Company, Madison, WI

Greg Paige

City Manager's Office, Eugene OR

Mary Procter

U.S. Congressional Office of Technology Assessment, Washington, DC

Eric Pulliam

San Diego County Energy Office, San Diego, CA

Mr. Purdy

J \& J Solar Inc., Phoenix, AZ

Diana Rains

Solar Office, California Energy Commission, Sacramento, CA 
Dusky Rhodes

Richard Stoll

Bert Tibbetts

Joane Wallach
Center for Renewable Resources, Washington, DC

U.S. Department of Energy; Energy Use Analysis, Washington, DC Solar Office, California Energy Commission, Sacramento, CA Minnesota State Energy Office, St. Paul, MN 


\section{APPENDIX B}

\section{ORDINANCES CITED}

Kauai, Hawaii

Calif ornia

Rhode Island

Santa Clara County, CA

Palo Alto, CA
Bill No. 601 , Ordinance No. 369, Section 5310, "Water Heating Systems." July 1979.

Assembly Bill No. 2036. Jan. 10, 1980. Amendment to Los Angeles Solar Tax Credit (not yet passed).

H. 7354, Amendment to Title 44 of the general laws. "An Act Relating to Energy Tax Credits." Feb. 14, 1980.

Conservaton and Solar Ordinances. Passed June 1980.

Solar Energy Program Proposal for the City. Jan. 1980. 


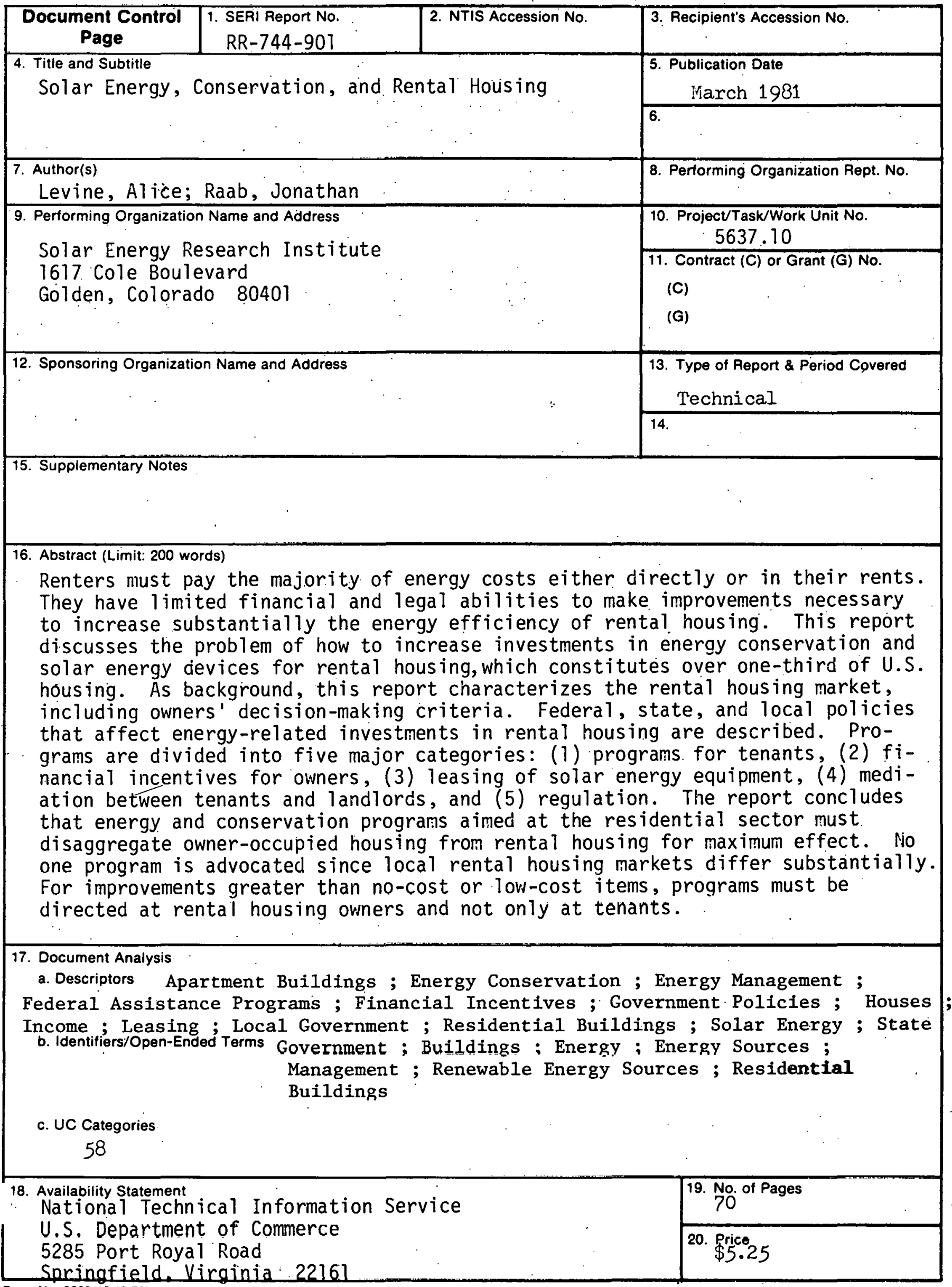

